\title{
THE AUXÍLIO EMERGENCIAL AND STRINGENT SOCIAL DISTANCING POLICIES IN BRAZIL: THE IMPACT ON MOBILITY AND NON-WORK TRAVEL OUTSIDE THE HOME
}

Auxílio emergencial e políticas rigorosas de distanciamento social no Brasil: o impacto sobre a mobilidade e as viagens fora de casa não relacionadas a trabalho

El programa de transferencia de emergencia y las políticas de aislamiento en Brasil: el impacto en la movilidad y en los viajes no laborales fuera del hogar

LORENA G. BARBERIA (1) lorenabarberia@usp.br ${ }^{1}$

KELLY SENTERS PIAZZA (1) kelly.piazza@afacademy.af.edu 2

\footnotetext{
1 University of São Paulo

2 United States Air Force Academy
}

Submission: 2021-06-04

Accepted: 2021-10-13

First View: 2021-11-22

Publication: 2021-11-08

Keywords:

auxílio emergencial; COVID-19; mobility; Brazil
Abstract

Non-pharmaceutical interventions to increase physical distancing have been instrumental in mitigating the spread of COVID-19. Governments have enacted stringent public health policies that impose limits on mobility outside the household. However, for containment policies to be effective, there is a growing understanding that emergency aid programs must be designed to ensure that the most vulnerable receive financial and in-kind aid resources to support their ability to "stay at home." In this study, we use survey data from an Oxford- 


\begin{tabular}{|c|c|}
\hline & $\begin{array}{l}\text { USP-FGV collaborative research initiative to empirically assess the effective- } \\
\text { ness of these two policies in reducing mobility with an eye to those at-risk or } \\
\text { living in conditions of poverty in eight Brazilian capitals. We learn that, in gen- } \\
\text { eral, neither stringent public health policies and receipt nor promised receipt of } \\
\text { the Auxílio Emergencial were effective in limiting mobility outside of the home. } \\
\text { We do, however, find limited evidence that receipt or promised receipt of the } \\
\text { Auxílio Emergencial marginally limited non-work trips outside of the home, } \\
\text { especially in city/state combinations with stringent public health policies. We } \\
\text { conclude by discussing the policy implications of our findings. }\end{array}$ \\
\hline $\begin{array}{l}\text { Palabras clave: } \\
\text { auxílio } \\
\text { emergencial; } \\
\text { COVID-19; } \\
\text { mobilidade; } \\
\text { Brasil. }\end{array}$ & $\begin{array}{l}\text { Resumen } \\
\text { Intervenções não-farmacológicas para aumentar o distanciamento físico têm sido } \\
\text { fundamentais para mitigar a disseminação da COVID-19. Os governos promul- } \\
\text { garam políticas de saúde pública rigorosas que impõem limites à mobilidade fora } \\
\text { do lar. No entanto, para que as políticas de contenção sejam eficazes, há um } \\
\text { entendimento crescente de que os programas de assistência emergencial devem } \\
\text { ser projetados para garantir que os mais vulneráveis recebam auxílio financeiro e } \\
\text { em espécie, para sustentar sua capacidade de "ficar em casa". Neste estudo, usa- } \\
\text { mos dados do questionário de uma iniciativa de pesquisa colaborativa Oxford- } \\
\text { USP-FGV, para avaliar empiricamente a eficácia dessas duas políticas na redução } \\
\text { da mobilidade, com foco em pessoas em situação de risco ou vivendo em con- } \\
\text { dições de pobreza em oito capitais brasileiras. Descobrimos que, em geral, nem } \\
\text { as rigorosas políticas públicas de saúde e nem o recebimento ou promessa de } \\
\text { recebimento do Auxílio Emergencial foram eficazes para limitar a mobilidade fora } \\
\text { de casa. Encontramos, entretanto, evidências limitadas de que o recebimento ou } \\
\text { a promessa de recebimento do Auxílio Emergencial limitaram marginalmente as } \\
\text { viagens fora de casa não relacionadas a trabalho, especialmente em combinações } \\
\text { de cidade/estado com políticas de saúde pública rigorosas. Concluímos discutin- } \\
\text { do as implicações de nossas descobertas sobre as políticas públicas. }\end{array}$ \\
\hline $\begin{array}{l}\text { Palavras-chave: } \\
\text { programas de } \\
\text { transferencia } \\
\text { de emergencia; } \\
\text { COVID-19; } \\
\text { movilidad; Brasil }\end{array}$ & $\begin{array}{l}\text { Resumo } \\
\text { Las intervenciones no farmacéuticas para aumentar el aislamiento físico han } \\
\text { sido fundamentales para mitigar la propagación del COVID-19. Los gobiernos } \\
\text { promulgaron estrictas políticas que imponen límites a la movilidad fuera del } \\
\text { hogar. Sin embargo, para que estas políticas de contención sean efectivas, } \\
\text { existe un creciente entendimiento de que los programas de transferencia de } \\
\text { emergencia deben diseñarse para garantizar que los más vulnerables reciban } \\
\text { los recursos de ayuda financiera y/o en especie de forma que respalde la capa- } \\
\text { cidad de "quedarse en casa". En este estudio, utilizamos datos de encuestas de } \\
\text { una investigación colaborativa Oxford-USP-FGV para evaluar empíricamente } \\
\text { la efectividad de estas políticas en la reducción de la movilidad con miras a } \\
\text { las personas en riesgo o que viven en condiciones de pobreza en ocho capita- } \\
\text { les brasileñas. Los resultados indican que ni el recibo o el potencial de recibir } \\
\text { la transferencia de emergencia limito la movilidad fuera del hogar. Sin embar- } \\
\text { go, encontramos evidencia limitada de que la recepción de la transferencia de } \\
\text { emergencia limitó marginalmente los viajes fuera del hogar para viajes no rela- } \\
\text { cionados a trabajo, especialmente en ciudades/estados con políticas de conten- } \\
\text { ción mas estrictas. Concluimos discutiendo las implicaciones para las políticas } \\
\text { de nuestros hallazgos. }\end{array}$ \\
\hline
\end{tabular}


LORENA G. BARBERIA AND KELLY SENTERS PIAZZA

THE AUXÍLIO EMERGENCIAL AND STRINGENT SOCIAL DISTANCING POLICIES IN BRAZIL:

THE IMPACT ON MOBILITY AND NON-WORK TRAVEL OUTSIDE THE HOME

\section{INTRODUCTION ${ }^{1}$}

In response to the COVID-19 outbreak, governments have enacted stringent policies aimed at containment, including closure policies and policies aimed at restrictions of the movement of individuals outside their homes (Cheng et al., 2020; Hale et al., 2020). One of the unintended consequences of these efforts to curb the spread of infections is the costly reduction in economic activity (Adda, 2016). Governments quickly recognized that lower-income households would be constrained in their capacity to work from home, reduce work hours (paid or nonpaid), and limit trips outside the home to meet basic needs. Consequently, programs were introduced to provide emergency cash and in-kind aid for vulnerable groups in many countries (Gentilini et al., 2020).

While studies have separately explored the effectiveness of policies designed to reduce intra-personal contact (Hsiang et al., 2020; Weill et al., 2020; Jay et al., 2020) and social protection programs (Brewer and Tasseva, 2020; Gupta et al., 2020; Gutierrez-Romero, 2020) in containing the pandemic in developed and developing countries, research examining how these policies jointly interact to either enhance or reduce the effectiveness of policies designed to contain COVID-19 is limited. In this paper, we combine data on public health policies mandated at the subnational level in Brazil and public opinion data on access to social protection programs and mobility to empirically assess whether stringent public health policies and social protection programs influence Brazilians' self-reported number of trips outside of the home and number of reasons for non-work travel outside the home in eight capital cities.

\section{THE ROLE OF SOCIAL DISTANCING POLICIES AND SOCIAL PROTECTION IN RESPONSE TO COVID-9 IN LATIN AMERICA}

The first COVID-19 case in Latin America was reported in São Paulo, Brazil in late-February 2020. In the months that followed, the pandemic spread beyond São Paulo both to rural regions and to other countries in the region. As a result, although Latin America has 8.2 percent of the world population (640 million people) and SARS-CoV-2 arrived relatively later than in Asia, Europe and North America, Latin America and the Caribbean countries had almost 16 percent of the world's cases (13 million) and more than 22 percent of all deaths $(418,041)$ by the end of 2020 (Ritchie et. al, 2021).

1. The views expressed in this article are those of the author and do not necessarily reflect the official policy or position of the United States Air Force Academy, the Air Force, the Department of Defense, or the U.S. Government. PA\#: USAFA-DF-2021-342. 
LORENA G. BARBERIA AND KELLY SENTERS PIAZZA

THE AUXÍLIO EMERGENCIAL AND STRINGENT SOCIAL DISTANCING POLICIES IN BRAZIL: THE IMPACT ON MOBILITY AND NON-WORK TRAVEL OUTSIDE THE HOME

With the onset of the pandemic in the hemisphere (around mid-March 2020), most Latin American governments issued orders closing businesses and schools. In most countries in the region, these social distancing policies remained in effect throughout 2020 though the stringency level of these policies varied widely over time and across countries.

Scholars, policymakers, and others have directed efforts to identify whether and the extent to which these social distancing policies reduced population mobility. In alignment with research in other regions of the world (Hsiang et al., 2020), country-specific studies for Latin America generally discerned that higher levels of stringency in social distancing policies were more effective in reducing population mobility (for the Brazilian case, see Barberia et al., 2021) and COVID-19 cases (for the case of Chile, see Bennett 2021).

As governments and populations mobilized to slow the spread of the virus, many of the economies in the region witnessed rapid and dramatic economic shocks, with marked rises in unemployment and poverty (Bargain \& Aminjonov, 2021). It quickly became clear that high shares of the population employed in service-sectors were unable to work remotely or reduce work hours and that government assistance would be particularly important to ensure that vulnerable households would be able to survive the massive economic shock. As a result, to accompany social distancing policies, many governments in the region enacted new or augmented existing social protection programs. In most countries, these social protection programs were designed both to deliver assistance through emergency cash transfers and in-kind food assistance and to protect households' access to basic utilities (Lustig and Trasberg, 2021). In general, beneficiaries of these programs included individuals in low-income households, many of whom were involved in existing (non-) contributory social schemes and government-run assistance programs. Some countries, including Brazil, extended benefits to also include those at risk and not covered by existing programs. Other countries, to include Mexico, Ecuador, and Colombia, deviated from regional trends either by not instituting a national-level income assistance program in response to the pandemic (in the case of Mexico) or by adopting more limited aid programs (in the cases of Ecuador and Colombia).

In their review of the responsiveness of social programs to the pandemic, Blofield, Giambruno, and Filgueira (2020) underscore the extensive welfare protection conferred by these programs and establish a foundation for research directed at examining the impact of these programs on the effects on household welfare, specifically. Londoño-Vélez and Querubin (2021) contribute to research in this area with a randomized control trial to study Colombia's unconditional cash transfer program designed to target one million households in poverty. They demonstrate that the program had positive (albeit modest) effects on measures of household well-being (e.g., financial health, food access). Levy and Menezes-Filho 
(2021) add to knowledge accumulated on this topic through their evaluation of the impact of the Brazilian federal emergency cash program on female labor supply. Ultimately, they uncover a small, negative, short-run impact of this program, raising concerns relating to program equity.

Although many have reasoned that compliance with social distancing policies is a particular challenge for poor workers, who have limited savings and critically rely on labor to cover basic needs for survival, studies have not yet tested whether and how receipt or promised receipt of transfers from social protection programs influences non-labor-related mobility independently and jointly with social distancing policies. In this paper, we address this topic in the case of Brazil.

\section{THE BRAZILIAN CASE}

In mid-March 2020, Brazilian state and municipal governments, primarily, began enacting public health policies in an effort to slow both the spread of COVID-19 and the country's rising death counts (Barberia et al., 2020). Backed by the Brazilian Supreme Court's April 2020 ruling, states and municipal governments were entrusted with the authority to implement restrictive measures in response to the pandemic (with local governments given the highest level of authority to increase containment measures in cases in which federal and state regulations are more permissive). ${ }^{2}$

Although no Brazilian state or city enacted lockdowns as stringent as those adopted in Wuhan, Spain, or Italy, many Brazilian states and state capitals adopted school, commerce, service, and industrial activity closure mandates in the early months of the pandemic. The stringency of adopted public health policies varied notably across time and across the 26 states of the Brazilian federation (Barberia et al., 2020), not to mention substantial discrepancies at the municipality level (de Souza et al., 2021). For illustration, cities, such as Fortaleza, Ceará in the Northeast, and Porto Alegre, Rio Grande do Sul in the South, adopted comparatively stringent social distancing policies whereas other cities such as Manaus, Amazonas in the North and Rio de Janeiro, Rio de Janeiro in the Southeast enacted comparatively less social distancing policies.

Concomitant with these social distancing policies, Brazilian federal, state, and municipal governments developed social protection programs to provide financial and in-kind support to the individuals and households most severely impacted by the COVID-19 pandemic. The largest of these social protection programs in

2. The ruling is available at:

http://www.stf.jus.br/arquivo/cms/noticiaNoticiaStf/anexo/ADPF672liminar.pdf. 
LORENA G. BARBERIA AND KELLY SENTERS PIAZZA

THE AUXÍLIO EMERGENCIAL AND STRINGENT SOCIAL DISTANCING POLICIES IN BRAZIL: THE IMPACT ON MOBILITY AND NON-WORK TRAVEL OUTSIDE THE HOME

Brazil both in terms of scope and in terms of the cash amount of the benefit provided to recipients is the Emergency Income Program - the Auxilio Emergencial Program (AEP). The Brazilian federal government introduced this program in Law $13.982 / 2020$ and Decree $10.316 / 2020$ with the goal of providing cash transfers to minimize the hardship of the pandemic for at-risk Brazilians. Beneficiaries of the Auxilio Emergencial Program were to include low-income informal workers, those self-employed, those already registered in Bolsa Família, and those satisfying established income earnings (that enabled a large share of the population to qualify for the benefit). Initially, the Auxilio Emergencial Program provided eligible Brazilians with three payments of BRL600.00 (a payment equivalent to nearly $60 \%$ of the monthly national minimum salary). By April 2020, 48,720,875 Brazilians had received program payments. ${ }^{3}$ To put the scope of the program in perspective, nearly one in four Brazilians received this transfer payment in April and May 2020. ${ }^{4}$

While encouraging, the design of the Auxilio Emergencial program may have inadvertently triggered mobility outside the home at a time when social distancing policies discouraged travel outside of the home to reduce the spread of the virus. A significant challenge in developing countries, such as Brazil, is ensuring that support (such as that provided as a part of the Auxilio Emergencial Program) reaches eligible people quickly. Unreliable or incomplete electronic records make this difficult. As such, the Brazilian federal government decided to distribute Auxilio Emergencial payments in two formats: 1) physical distribution at the federal government's state-owned bank, the Caixa Econômica Federal and 2) electronic distribution with a digital mobile application (Prates et al., 2020). Without smartphones and/or internet access, the only option for many eligible Brazilians to obtain funds was to visit the Caixa Econômica Federal. This means that, by design, the Auxilio Emergencial Program triggered mobility. Long queues and large public gatherings at bank offices and nearby storefronts in the early months of the program's rollout substantiate this claim.

In this paper, we estimate multivariate regression models to assess whether social distancing policies and social protection programs independently and jointly

3. The number of recipients in April and May are based on calculations using: http://www.portaldatransparencia.gov.br/pagina-interna/603519-download-de-dados-auxílio-emergencial and verified by journalists and data scientists in this article: https://g1.globo.com/economia/noticia/2020/06/06/ em-3547-municipios-do-brasil-pelo-menos-14-dos-habitantes-recebeu-o-auxílio-emergencial.ghtml. The total number of beneficiaries was $53,919,640$ in these two months. IBGE estimates that there were 210,147,125 Brazilians in 2019. For more detailed information, see: https://www.ibge.gov.br/ estatisticas/sociais/populacao/9103-estimativas-de-populacao.html?=\&t=resultados.

4. On June 30, the Brazilian government extended benefits for two additional months (Decree 10.412/2020) with the same payment amount, and debates are currently underway to determine whether the benefit will be extended given the prolonged severity of the pandemic. 
impact non-work trips outside the home among those at risk or living in conditions of poverty in eight Brazilian state capitals. We learn that, in general, both stringent social distancing policies and receipt or promised receipt of the Auxilio Emergencial were ineffective in limiting mobility outside of the home. We do, however, find limited evidence that receipt or promised receipt of the Auxilio Emergencial marginally limited non-work trips outside of the home, especially in city/state combinations with stringent social distancing policies. We conclude that these policies need to be adapted in order to mitigate the pandemic-wrought devastation.

\section{DATA AND METHODS}

The primary data that we use to assess the impact of social distancing policies and social protection programs comes from an Oxford-USP-FGV collaborative public opinion survey with a representative sample of Brazilians in eight state capitals (Petherick et al., 2020), the COVID-19 Government Response Tracker for the Brazilian Federation (CGRT-BRFED) (Barberia, et al., 2020), and the Oxford COVID-19 Government Response Tracker (OxCGRT).

The Oxford-USP-FGV collaborative public opinion survey was conducted over the phone between 6 and 27 May 2020 (coinciding with the initial disbursement of Auxilio Emergencial Program payments). The sample was randomized and stratified by age, sex, income, and education level. Two hundred citizens were interviewed in the Brazilian cities of Fortaleza, Goiania, Manaus, Rio de Janeiro, Recife, Salvador, and Porto Alegre, and 250 citizens were interviewed in São Paulo. The survey includes questions that capture individual adherence to social distancing policies, status relating to the Auxílio Emergencial Program, susceptibility to COVID-19, and demographic information, among other topics. As such, it informs our dependent variables, one of our primary independent variables, and some of our control variables.

In this paper, we consider two primary dependent variables, both of which rely on responses to questions that ask Oxford-USP-FGV survey respondents about trips outside of the home. With our first dependent variable, we consider the number of times that respondents reported leaving their homes in the two weeks prior to survey enumeration. On average, survey respondents reported having left their homes 3.64 days (standard deviation of 2.925) in the weeks leading up to the survey.

With our second dependent variable, we consider survey respondents' explained reasons for leaving their homes. The Oxford-USP-FGV survey asks survey respondents whether they left their homes to go to the bank, for essential supplies, 
to exercise, for professional events, ${ }^{5}$ for public events, to go to the supermarket, to use public transportation, to travel, to visit friends and family, or for other reasons. Figure 1 shows the distribution of Oxford-USP-FGV respondents' self-reports of reasons for leaving the house. As the figure underscores, the most common reasons for leaving the home are for essential purchases of supplies and food.

Figure 1. Percentage of Survey Respondents Self-Reporting Leaving Home During May 2020

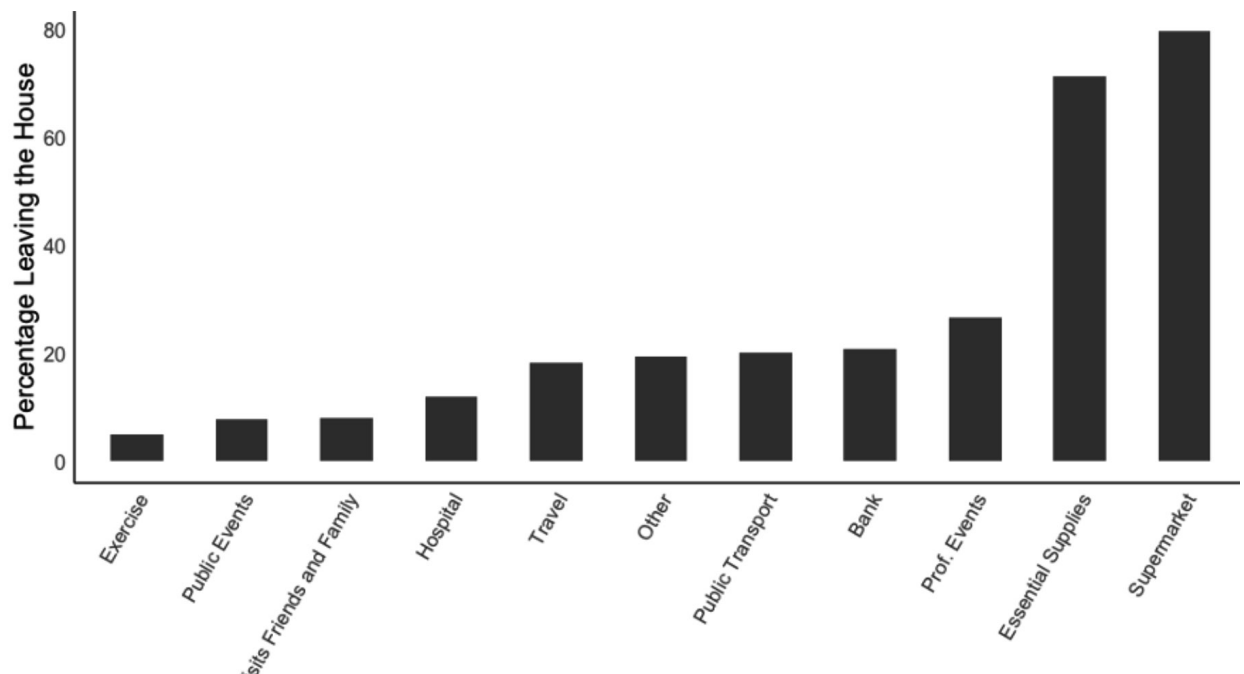

Reasons for Leaving the House

Source: Petherick, Kira, Goldszmidt, and Barberia (2020).

We use responses to these questions to construct an additive index of nonwork travel for our second dependent variable. We consider visiting family and friends, exercising, traveling, taking public transportation, attending professional events, and attending public events to be non-work-related trips outside of the home discouraged by social distancing policies. On a scale from 0 to 6 , survey respondents expressed having left their homes for approximately one of these non-work trips (standard deviation of 1.00) in the two weeks prior to survey enumeration.

5. The survey does not inquire specifically about leaving the home for work. It does ask if about leaving the home for professional events, which we assume leaving the home for work and work-related activities. 
LORENA G. BARBERIA AND KELLY SENTERS PIAZZA

THE AUXÍLIO EMERGENCIAL AND STRINGENT SOCIAL DISTANCING POLICIES IN BRAZIL: THE IMPACT ON MOBILITY AND NON-WORK TRAVEL OUTSIDE THE HOME

We hypothesize that both social distancing policy stringency and Auxílio Emergencial status independently and jointly help to explain variation in our two dependent variables. More pointedly, we suspect that Brazilians living in states and cities with comparatively stringent social distancing policies are less mobile than their counterparts living in states and cities with comparatively less stringent policies. We anticipate that the Auxilio Emergencial will trigger mobility involving bank visits but reduce non-work travel outside the home. We hypothesize that Auxilio Emergencial recipients in states and cities with stringent public health policies will be especially likely to limit their non-work travel outside of the home.

To test these hypotheses, we leverage responses to Oxford-USP-FGV survey questions on both Auxilio Emergencial status and state/city of residence (which we pair with data on social distancing policy stringency from the COVID-19 Government Response Tracker for the Brazilian Federation (CGRT-BRFED) (Barberia et al., 2020) and the Oxford COVID-19 Government Response Tracker).

To assess our hypothesis relating to social distancing policy stringency, we consider responses to the Oxford-USP-FGV public opinion survey's question on city and state of residence. ${ }^{6}$ To interpret the significance of these responses, we merge these with data from the COVID-19 Government Response Tracker for the Brazilian Federation (CGRT-BRFED) (Barberia et al., 2020) and the Oxford COVID-19 Government Response Tracker (OxCGRT). These sources include indices that capture social distancing policy stringency at each government level in the Brazilian federation on the basis of 1) the stringency of policies surrounding school, business, and industry closures and of restrictions concerning public and private gatherings and 2) geographic scope of policies (where policies evenly mandated across entire states and cities result in higher stringency scores and where policies unevenly mandated across entire states and cities result in lower stringency scores). The social distancing policy stringency indices are calculated by adding together the ordinal policy score and the ordinal geographic score for each indicator, finding the average, and rescaling this value on a scale from 0 (extremely low stringency) to 100 (extremely high stringency). Figure 3 depicts the mean social distancing policy stringency index score for the 8 capital cities and their respective states (plus Belo Horizonte, Minas Gerais) over the March 1, 2020 to May 31, 2020 period. This figure suggests that there is considerable variation among the Brazilian cities and states under consideration over the three-month period, with some cities like Fortaleza, Ceará adopting comparatively stringent policies and other countries like Manaus, Amazonas adopting comparatively less stringent policies.

6. Given that the survey only contains responses to those who live in the capital, we are unable to explore the effect of capital versus state-level policy stringency on mobility patterns. 
Figure 2. Social Distancing Policy Stringency (Mean Capital and State Stringency Level from March to May 2020)
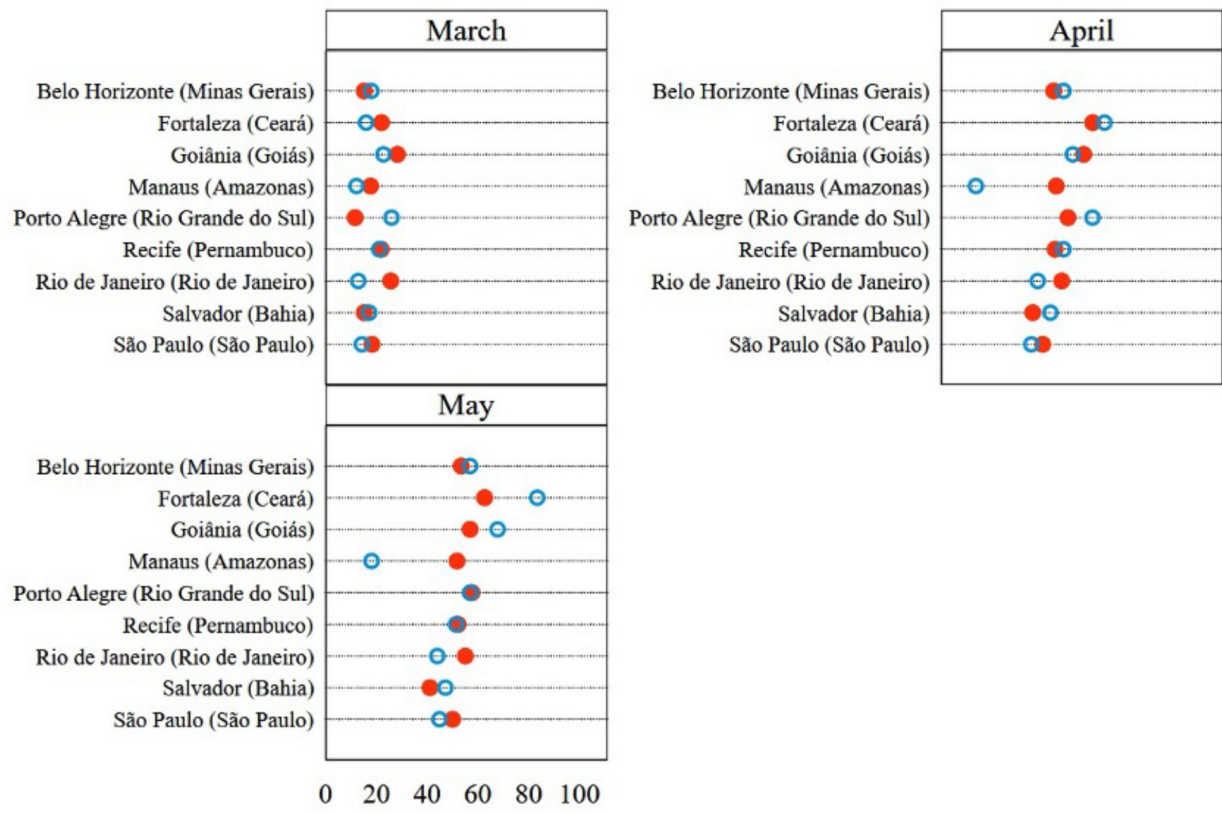

Capitals States

Source: Barberia et al. (2020).

For the purposes of this paper, we are primarily interested in the stringency of social distancing policies in the two weeks prior to survey enumeration ( 6 and 27 May 2020), corresponding with the time period primed in the questions informing our dependent variables. For the sake of simplicity, we consider the stringency of social distancing policies in place on 22 April 2020 - two weeks prior to the start of survey enumeration (6 May 2020). Table 1 documents these and highlights the city/state combinations with the most (Porto Alegre, RS) and least (Rio de Janeiro, $\mathrm{RJ}$ ) stringent policies in bold (as determined using the regulation that Brazilians are required to comply with the most stringent policies in their jurisdictions). 
LORENA G. BARBERIA AND KELLY SENTERS PIAZZA

THE AUXÍLIO EMERGENCIAL AND STRINGENT SOCIAL DISTANCING POLICIES IN BRAZIL: THE IMPACT ON MOBILITY AND NON-WORK TRAVEL OUTSIDE THE HOME

Table 1. Brazilian City and State Social Distancing Policy Stringency on 22 April 2020

\begin{tabular}{lccc}
\hline \multicolumn{1}{c}{ City } & Stringency City & State & Stringency State \\
\hline Manaus & 15.28 & $\mathrm{AM}$ & 45.83 \\
Fortaleza & 45.83 & $\mathrm{CE}$ & 40.28 \\
Recife & 47.22 & $\mathrm{PE}$ & 59.72 \\
Salvador & 47.22 & $\mathrm{BA}$ & 56.94 \\
Rio de Janeiro & 43.75 & $\mathrm{RJ}$ & 45.14 \\
São Paulo & 37.5 & $\mathrm{SP}$ & 48.61 \\
Porto Alegre & 68.06 & $\mathrm{RS}$ & 45.83 \\
Goiânia & 59.72 & $\mathrm{GO}$ & 38.89 \\
\hline
\end{tabular}

Source: Barberia et al. (2020).

To assess our hypothesis related to the Auxilio Emergencial status, we rely on the Oxford-USP-FGV survey's question that asks respondents to self-report eligibility for the Auxilio Emergencial. ${ }^{7}$ Figure 3 documents the proportion of survey respondents in each of the nuanced response categories, disaggregated to assess whether respondents had already received a payment or were expecting to receive a payment.

7. The question in Portuguese states, "Vamos falar agora do Auxílio Emergencial (no valor de R\$ 600). Ao longo do mês passado, quais das seguintes opções se aplica a você: a) Eu não sou elegível e não me inscrevi para recebê-lo; b) Eu sou elegível, mas não me inscrevi; c) Eu me inscrevi, mas fui considerado não elegível; d) Eu me inscrevi e fui considerado elegível, mas ainda não recebi o auxílio; e) Recebi pelo menos uma parcela do Auxílio Emergencial de $R \$ 600$ e, f) Não sei o que é/Não ouvi falar do Auxílio Emergencial." 
LORENA G. BARBERIA AND KELLY SENTERS PIAZZA

THE AUXÍLIO EMERGENCIAL AND STRINGENT SOCIAL DISTANCING POLICIES IN BRAZIL: THE IMPACT ON MOBILITY AND NON-WORK TRAVEL OUTSIDE THE HOME

Figure 3. Oxford-USP-FGV Respondents' Self-Reported Eligibility and Application for the Auxilio Emergencial (R $\$ 600)$

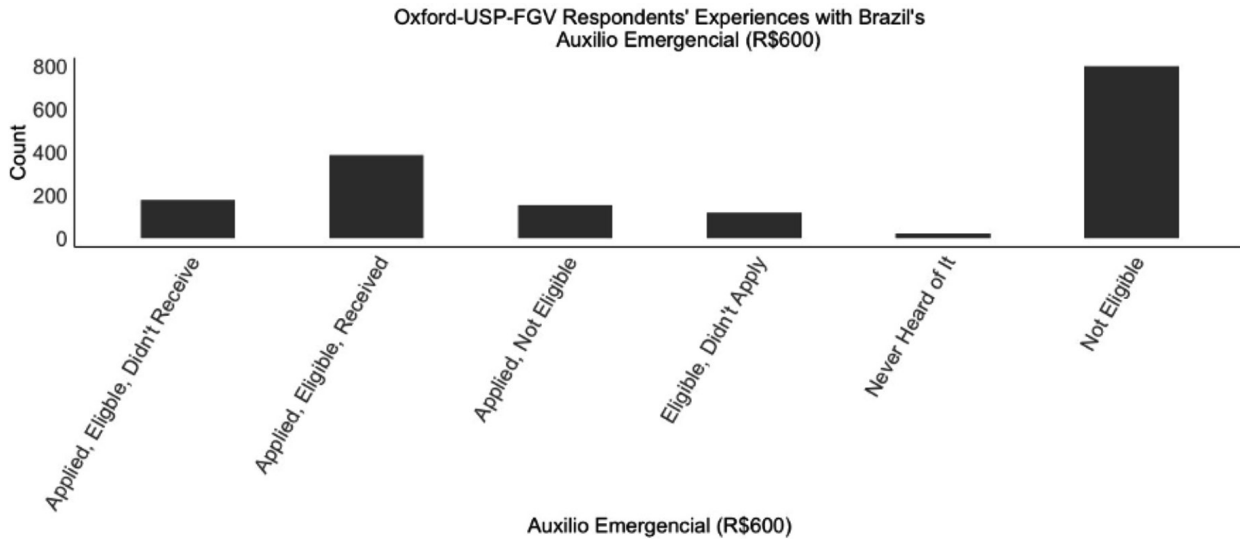

Source: Petherick, Kira, Goldszmidt, and Barberia (2020).

In our regression estimations, we operationalize our primary Auxilio Emergencial status independent variable in two distinct ways. First, we consider both survey respondents who received at least one installment from the emergency program and who applied to receive the Auxilio Emergencial but had not yet received it as Auxilio Emergencial recipients. Then, we consider solely survey respondents who received at least one installment from the emergency program at the time of survey enumeration as Auxílio Emergencial Program recipients.

In addition to informing one of our primary independent variables, we use responses to this question to construct various samples for our regression analyses, aimed at assessing whether financial assistance from the Auxilio Emergencial Program influences mobility outside the home among the most vulnerable in eight Brazilian capitals. We, first, compare Auxílio Emergencial recipients (operationalized as only those who applied for or were automatically applied for and received the Auxilio Emergencial) 1) those who were not eligible, 2) those who were not eligible but applied, and 3) those who were eligible but did not apply, and 4) those who were eligible and applied but are waiting to receive the emergency transfer. We, then, compare Auxilio Emergencial recipients (operationalized as both those who applied for or were automatically applied for and received or are waiting to receive the Auxilio Emergencial) with 1) those who were not eligible, 2) those who were not eligible but applied, and 3) those who were eligible but did not apply. Making these nuanced comparisons helps us to better understand the impact of the Auxilio Emergencial in inducing compliance with social distancing practices understood to curtail the spread of the virus. 
LORENA G. BARBERIA AND KELLY SENTERS PIAZZA

THE AUXÍLIO EMERGENCIAL AND STRINGENT SOCIAL DISTANCING POLICIES IN BRAZIL: THE IMPACT ON MOBILITY AND NON-WORK TRAVEL OUTSIDE THE HOME

To assess the independent and interactive influence of the Auxilio Emergencial and social distancing policy stringency on general travel and non-work trips outside of the home, we need to control for plausible confounding factors. An obvious confounder is COVID-19 symptoms. Chiefly, we suspect (and hope) that those with identifiable symptoms are less likely to leave their homes for any reason than their counterparts without identifiable symptoms. We control for COVID-19 symptoms using responses to Oxford-USP-FGV public opinion survey questions that ask respondents about whether they recently experienced fever, dry cough, lack of air, loss of smell, and loss of taste and whether they have a pre-existing health condition that increases the severity of infection from COVID-19. ${ }^{8}$ Using a machine-learning algorithm combined with a multivariate binomial logistic regression, we calculated the weights of the likelihood of COVID-19 infection based on the reported symptoms and clinical conditions based on a study of 30 studies involving 53,000 participants (Ma et al., 2020). From the estimate of these weights, we calculate a COVID-19 infection risk score for each respondent in the Oxford-USP-FGV survey on the basis of both reported symptoms and clinical history of the disease. In our sample, the risk score for COVID-19 infection ranged from 0 to a maximum of 5.09, where higher scores signify higher likelihood of COVID-19 infection. Approximately $25 \%$ of respondents received scores greater than zero. However, only $8.1 \%$ of the sample received scores in the range between 1 and 5.09.

The advantage of this particular measure of COVID-19 susceptibility over self-reports of individual COVID-19 symptoms is that it utilizes numerous COVID symptoms and weighs them by known parameters calculated by Ma et al. (2020). Thus, respondents with symptoms that have a higher likelihood of COVID-19 infection (e.g., loss of smell) are given higher scores than respondents with symptoms that have a lower likelihood of COVID infection (e.g., fever). Based on the results reported by Ma et al. (2020), higher scores are awarded to those who have a pre-existing medical condition that may increase the severity of their symptoms. Absent widespread testing, this is a meaningful indicator of COVID susceptibility, but it is worth highlighting that this score is not confirmatory.

Aside from COVID-19 susceptibility, we control for conventional individual-level variables that may contribute to differences in mobility and are intuitively related to the COVID-19-specific dynamics considered in our analysis. Specifically, we control for gender, race, number of neighbors, education, and household income movement. In line with Caselli et al.'s (2020) result that lockdowns reduce women's mobility more than men's and Woskie and Wenham's (2021)

8. The question in Portuguese states, "P34. Quais dos seguintes sintomas você teve nos últimos 7 dias? Não inclua aqueles que você normalmente sente devido a algum problema de saúde que você já conhece (marcar todos os que se aplicam): a) Febre; b) Tosse seca; c) Falta de ar; d) Perda de olfato; e) Perda de paladar; ou f) Nenhum desses sintomas. 
finding of fewer visits to community locations on women-mobility days in Panama, we suspect that women may be more likely to limit mobility and less likely to travel outside the home for non-work reasons. In response to near consensus that COVID-19 has had disproportionate health impacts on racial and ethnic minorities in Brazil (e.g., Ribeiro et al., 2021; Peres et al., 2021; Li et al., 2020), we suspect that non-white Brazilians, in comparison with white Brazilians, may be more likely to limit mobility and less likely to travel outside the home. However, we also suspect that, despite grave health concerns, non-white Brazilians of lower socioeconomic backgrounds may be more likely to leave the home in search of work. To account for these possibilities, we control for gender and race. Survey respondents who are female and white take on a value of 1 , and survey respondents who are male and non-white take on a value of 0 on the first two control variables, respectively.

We also control for the number of neighbors, education, and household income movement. The number of neighbors captures the number of neighbors that respondents report as living within proximity of their household, education captures education level ranging from illiterate (no formal education) to post-graduate (complete/incomplete), and household income movement ranges from 1 (decline in income post-COVID-19) to 3 (increase in income post-COVID-19). We suspect that each of these variables may be important. Chiefly, we suspect that those living in more dense urban areas may be less likely to leave the home for non-work reasons and that those with lower levels of education and having suffered income loss may be more likely to leave their homes in search of money.

We use two different types of regression models to estimate the effect of the Auxilio Emergencial and social distancing policy stringency on non-work trips outside of the home, controlling for the potential confounders as identified above. Specifically, we estimate ordinary least squares models for models involving our first dependent variable - number of trips outside the home in the prior twoweek period - and ordinal logistic regression models for models involving our first dependent variable - number of non-work reasons for leaving the house in the prior two-week period. Rio de Janeiro, the city/state combination with the least restrictive social distancing policies in place two weeks prior to the onset of survey enumeration, is the reference category in all models.

\section{RESULTS}

\section{Number of Trips Outside the Home}

Figures 4 and 5 contain the results of analyses considering our first dependent variable - the number of trips outside the home in the two weeks prior to survey 
enumeration. We explore the interactive effect of the Auxilio Emergencial and social distancing policies below in Figure 6. ${ }^{9}$

Figure 4. The Effect of Emergency Cash Transfers and Social Distancing Policies on Number of Trips Outside the Home (Auxílio=Auxílio Recipients + Promised Recipients)

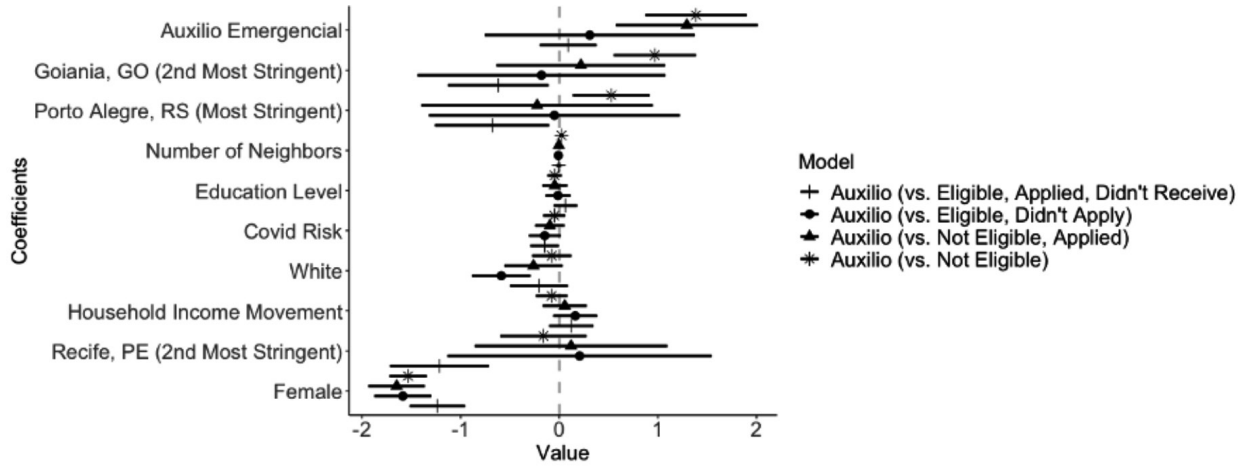

Source: Petherick et al. (2020); Barberia et al. (2020).

Figure 5. The Effect of Emergency Cash Transfers and Social Distancing Policies on Number of Trips Outside the Home (Auxílio=Auxílio Recipients Only)

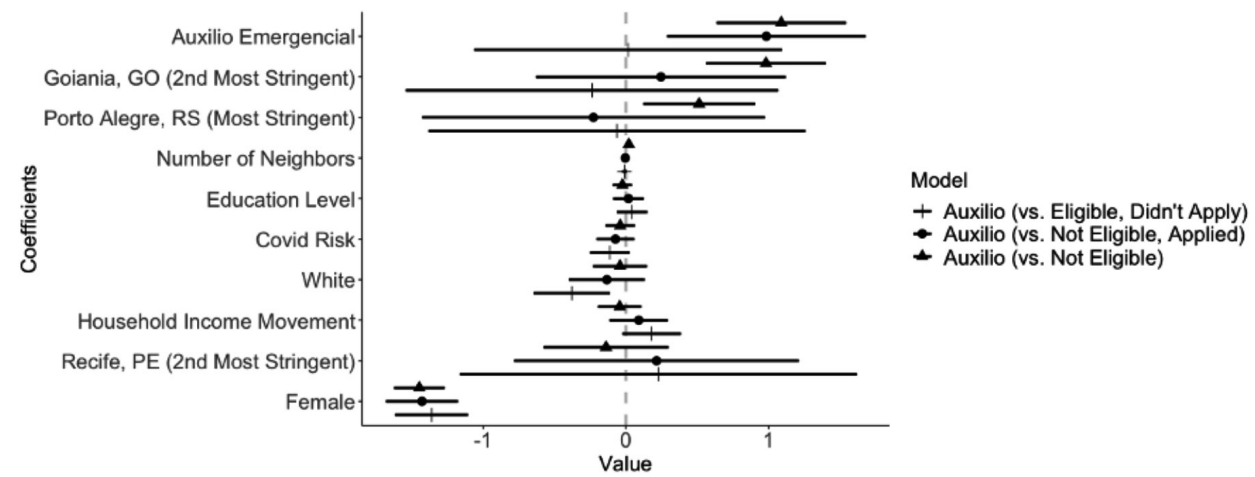

Source: Petherick et al. (2020); Barberia et al. (2020).

The results of our models refute our hypothesis that the stringency of social distancing policies curbs the number of trips outside of the home. In fact,

9. Appendix Tables 1 and 2 contain the full results. 
according to models estimated with some samples (chiefly, with samples comparing Auxilio Emergencial recipients and promised recipients to those ineligible to receive the Auxilio Emergencial), survey respondents in some cities and states with more stringent social distancing policies (Goiânia, Go and Porto Alegre, RS) were actually more likely to leave the home than their counterparts in Rio de Janeiro (the city/state combination with the least stringent social distancing policies). This is surprising and suggests that evidence in support of the effectiveness of stringent policies in limiting the number of trips outside the home among program beneficiaries is scant. In our discussion section, we identify some plausible explanations for this surprising finding.

Across all operationalizations of the group comprising receipt of the emergency transfer and samples selected for comparison, Auxílio Emergencial appears to have either a positive (at best) or insignificant effect on the self-reported number of trips outside the home. On the whole, those who received or were promised to receive the Auxilio Emergencial were no less likely to report leaving the house than their counterparts who were not eligible for the Auxilio Emergencial or who were eligible but did not apply. In addition, those who received the Auxilio Emergencial were no less likely to leave the home than their counterparts who were promised but had not yet received the Auxilio Emergencial. This evidence suggests that the structure of the social protection program and the nature of the rollout of funds was ineffective in curbing mobility. In fact, it may have spurred it.

While we find no evidence that social distancing policies or the Auxilio Emergencial were impactful in curbing the number of trips outside the home, we do uncover gender differences in mobility behaviors. Depending on the model and sample combination considered, we discern that woman in São Paulo, SP (the city/state with the most survey respondents) took between 1.26 and 1.65 fewer trips than men, holding all other variables at their mean values. This may help us to explain Ribeiro et al.'s (2021) finding that mortality rates were higher among men than women in São Paulo. Surprisingly, in models aimed to assess our first dependent variable, no other control variables are consistently statistically significant.

In addition to exploring the independent effects of social distancing policies, the Auxilio Emergencial, and control variables on the number of trips outside the home, we explore the interactive effect of the former. Figure 6 showcases the interactive results of our primary model with a sample comprised of those who received and those who were promised the Auxilio Emergencial, with only recipients comprising the treatment category. 
LORENA G. BARBERIA AND KELLY SENTERS PIAZZA

THE AUXÍLIO EMERGENCIAL AND STRINGENT SOCIAL DISTANCING POLICIES IN BRAZIL: THE IMPACT ON MOBILITY AND NON-WORK TRAVEL OUTSIDE THE HOME

Figure 6. Predicted Number of Days Outside the Home by Auxilio Emergencial Status and City, State, and Social Distancing Policy Stringency

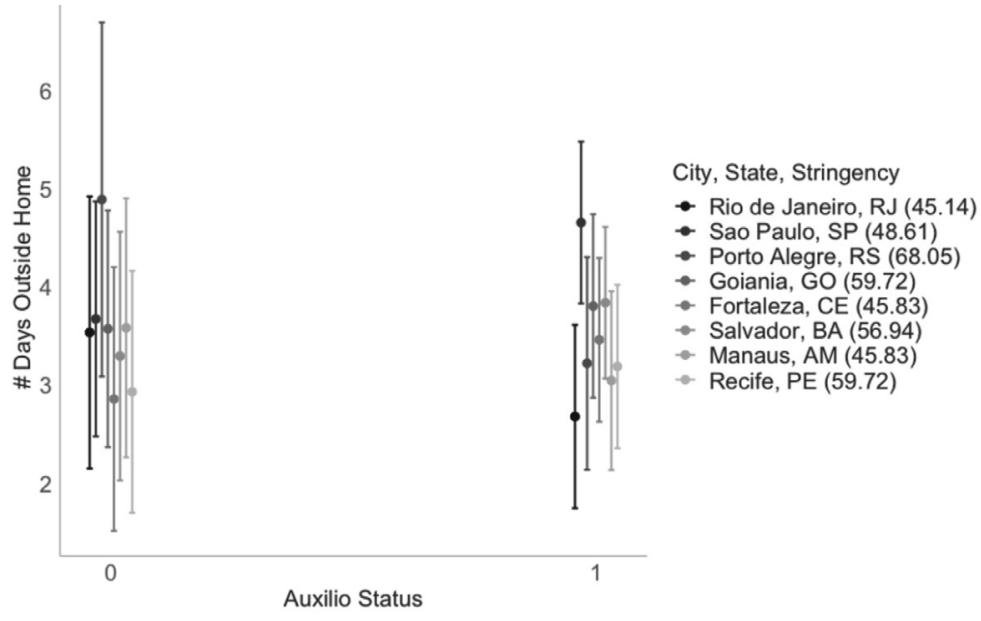

Source: Petherick et al. (2020); Barberia et al. (2020).

Figure 6 provides visual evidence that in nearly all city/state combinations, receipt of the Auxilio Emergencial marginally increased the number of trips outside of the home. For illustration, in the three most stringent city/state combinations (Porto Alegre, RS, Goiânia, GO, and Recife, PE), moving from the promised Auxilio Emergencial status to the received Auxilio Emergencial status increased the average number of days outside of the home by $0.09,0.09$, and 0.1 days, respectively. While not statistically significant, these findings are concerning insofar as the Auxilio Emergencial was designed not only to alleviate financial hardship but to provide recipients with the financial means necessary to comply with instated social distancing policies. On the latter objective, at minimum, the program appears to have missed its mark.

\section{NUMBER OF NON-WORK REASONS FOR LEAVING THE HOME}

Figures 7 and 8 contain the results of analyses considering our second dependent variable - the number of non-work reasons for leaving the house in the two weeks prior to survey enumeration. We explore the interactive effect of the Auxilio Emergencial and public health policies below in Figure 9.10

10. Appendix Tables 3 and 4 contain the full results. 

Recipients)

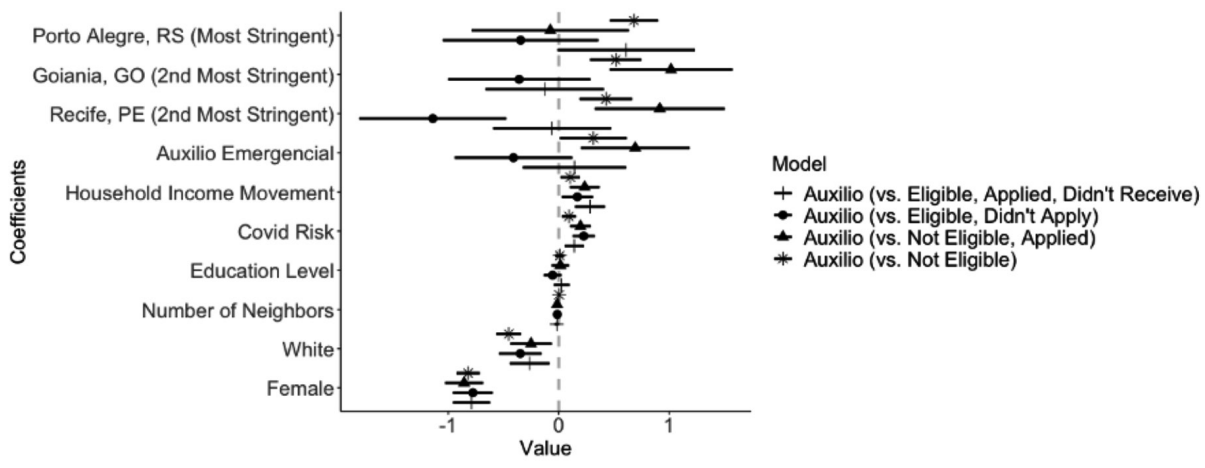

Source: Petherick et al. (2020); Barberia et al. (2020).

Figure 8. The Effect of Emergency Cash Transfers and Social Distancing Policies on Number of Reasons for Non-Work Trips (Auxílio=Auxílio Recipients Only)

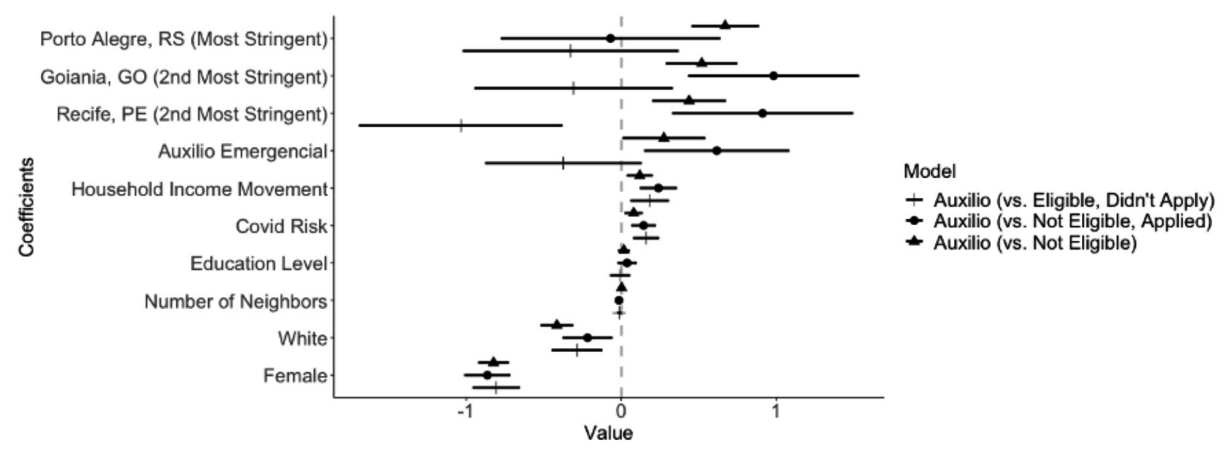

Source: Petherick et al. (2020); Barberia et al. (2020).

Similarly to models designed to assess the number of trips outside of the home, these models refute our hypothesis that the stringency of social distancing policies curbs non-work reasons for leaving the house. We learn that survey respondents in cities and states with more stringent containment policies were actually more likely to self-report leaving the home for non-work trips. This further corroborates our previously stated position related to the ineffectiveness of stringent policies in limiting non-work travel for reasons we discuss below.

Across all operationalizations of the group comprising receipt of assistance from the Auxilio Emergencial Program and samples selected for comparison, the 
LORENA G. BARBERIA AND KELLY SENTERS PIAZZA

THE AUXÍLIO EMERGENCIAL AND STRINGENT SOCIAL DISTANCING POLICIES IN BRAZIL: THE IMPACT ON MOBILITY AND NON-WORK TRAVEL OUTSIDE THE HOME

social protection program appears to have an insignificant effect on the self-reported number of reasons for non-work trips outside the home. On the whole, those who received or were promised to receive the Auxilio Emergencial were no less likely to report leaving the house for non-work trips than their counterparts who were not eligible for the Auxílio Emergencial or who were eligible but did not apply. In addition, those who received the Auxílio Emergencial were also no less likely to leave the home than their counterparts who were promised but had not yet received the Auxilio Emergencial. This contradicts our expectation.

In contrast with some of our primary independent variables of interest, some of our control variables - chiefly race, gender, COVID-19 risk, and household income movement- are statistically significant. As expected, by all of our modeling specifications and samples, women and white Brazilians self-report fewer reasons for non-work trips than men and non-white Brazilians. The magnitude of the gender effect is particularly striking. The predicted probability that women in São Paulo (the city/state with the most survey respondents) would take no non-work trips outside of the home was between $43 \%$ and $52 \%$, whereas the predicted probability that men in São Paulo would take no non-work trips outside of the home was between $26 \%$ and $33 \%$, depending on the sample considered and with all other variables held at their mean values. Statistically significant gender and race coefficients may help us to interpret recent studies uncovering that non-white men in Brazil are especially susceptible to mortality from COVID-19 (Ribeiro et al., 2021; Peres et al., 2021). Perhaps surprisingly, survey respondents with higher levels of susceptibility to COVID-19 and with increased incomes in the wake of the pandemic were marginally more likely to more likely to self-report more reasons for non-work travel outside the home. We might, however, make sense of the finding that those with higher levels of susceptibility to COVID-19 are more likely to engage in non-work travel if we recognize other social vulnerabilities of this population that may counteract impulses to stay at home. In contrast with our other control variables, education level and the number of neighbors were not statistically significant.

In addition to exploring the independent effects of social distancing policies and the Auxilio Emergencial on the number of non-work reasons for leaving the home, we explore the interactive effect. Figure 9 displays the interactive results of our primary model with a sample comprised of those who received and those who were promised the Auxilio Emergencial, with only recipients comprising the treatment category. 


\section{Stringency}

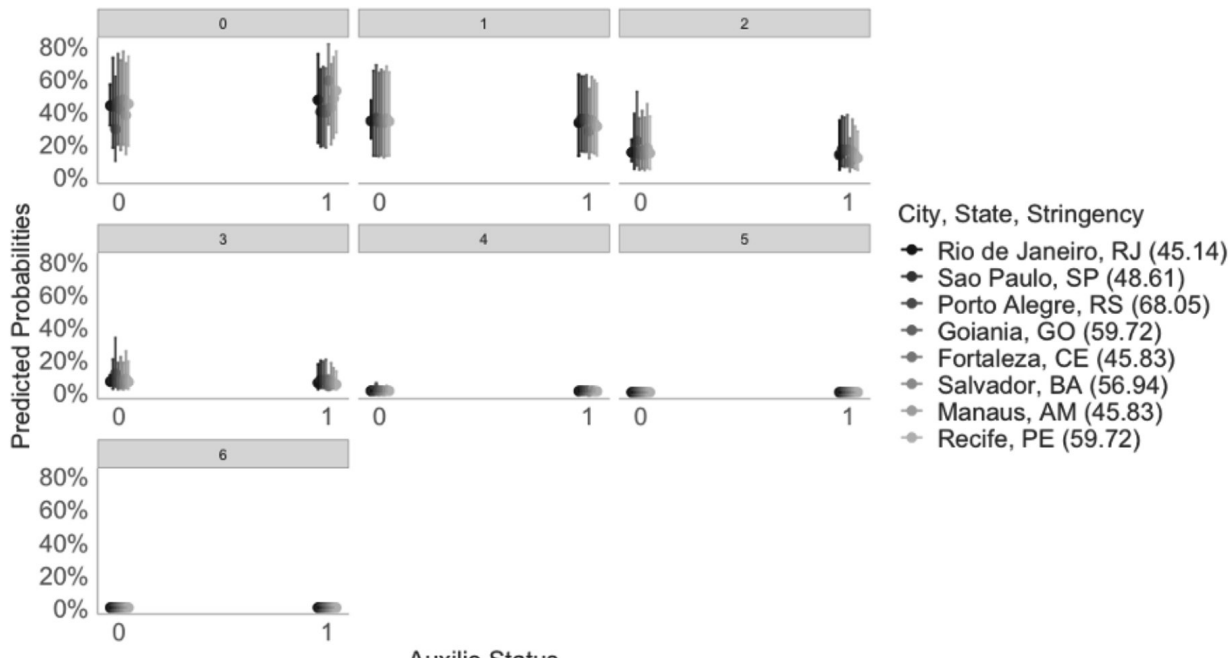

Auxilio Status

Source: Petherick et al. (2020); Barberia et al. (2020).

Figure 9 suggests that there are meaningful differences in Oxford-USP-FGV survey respondents' propensities to self-report the number of reasons for nonwork trips across cities and states and that the Auxilio Emergencial is more effective in compelling Brazilians to stay at home in some places than others. Among non-recipients of the Auxilio Emergencial, the predicted probability of not leaving the home for any non-work reason was $41.5 \%$ in Rio de Janeiro, Rio de Janeiro (the city/state combination with the least stringent social distancing policies), $27.4 \%$ in Porto Alegre, RS (the city/state combination with the most stringent social distancing policies), $44.2 \%$ in Goiânia, GO (the city/state combination tied for the second most stringent social distancing policies), and $42.5 \%$ in Recife, PE (the city/state combination tied for the second most stringent social distancing policies), holding all control variables in the model at their mean response. Among recipients of the Auxilio Emergencial, the predicted probability of not leaving the home for any non-work reason was $44.98 \%$ in Rio de Janeiro, Rio de Janeiro (the city/state combination with the least stringent social distancing policies), $38.8 \%$ in Porto Alegre, RS (the city/state combination with the most stringent social distancing policies), $37.4 \%$ in Goiânia, GO (the city/state combination tied for the second most stringent policies), and $50.4 \%$ in Recife, PE (the city/state combination tied for the second most stringent social distancing policies), holding all 
LORENA G. BARBERIA AND KELLY SENTERS PIAZZA

THE AUXÍLIO EMERGENCIAL AND STRINGENT SOCIAL DISTANCING POLICIES IN BRAZIL: THE IMPACT ON MOBILITY AND NON-WORK TRAVEL OUTSIDE THE HOME

control variables in the model at their mean response. With the exception of Goiânia, GO, the predicted probability of not leaving the home for any non-work reason increased for Auxilio Emergencial recipients in comparison with non-recipients for the states considered. In fact, moving from non- Auxilio Emergencial recipient to Auxilio Emergencial recipient status increased the predicted probability of not leaving the home for any non-work reasons in Porto Alegre, RS (the city/ state combination with the most stringent social distancing policies) by $11.8 \%$. This provides some evidence that receipt of the Auxilio Emergencial increases the probability that the most vulnerable in cities and states with stringent social distancing policies will stay home when able and mitigate the virus's spread.

\section{DISCUSSION}

In this paper, we assessed the independent and interactive influence of social distancing policies and Brazil's Auxílio Emergencial program on two different measures of mobility. Specifically, we learn that neither stringent social distancing policies nor receipt or promised receipt of the Auxilio Emergencial limited the self-reported number of trips that Brazilians took outside of their homes. In fact, if anything, we find that promised receipt of the Auxilio Emergencial actually increased mobility in terms of the number of trips outside of the home. Across all states, irrespective of the stringency of social distancing policies in place, we find that receipt or promised receipt of the Auxilio Emergencial marginally increased mobility of this form. We do, however, learn that the recipients or promised recipients of the Auxilio Emergencial were slightly more likely to report fewer reasons for non-work travel outside of the home. In fact, in some states with especially stringent social distancing policies, we find that receipt or promised receipt of the Auxilio Emergencial marginally increased the probability of not leaving the home for non-work reasons.

Taken together, we interpret these results as evidence that stringent social distancing policies were insufficient in compelling Brazilians to stay at home. We suspect that mixed messaging at different levels of government, a perceived lack of enforcement, and negligent leadership at the national level may contribute to the limited effectiveness of these policies.

We also deduce that the Auxílio Emergencial did not notably empower poor Brazilians to comply with social distancing policies. In fact, by the very nature of the program, it may, in fact, have spurred mobility (especially in terms of trips outside of the home). If policymakers' goals extend beyond providing subsistence means to vulnerable Brazilians and include providing these populations with the means to stay home and guard themselves against their disproportionately high susceptibility to COVID-19, the evidence in this study suggests that the Auxilio 
Emergencial, and the structure of the program, is insufficient. To address this, policymakers ought to consider increasing accessibility to digital transfers of funds or distributing funds in strategic locations (e.g., supermarkets, pharmacies, etc.) to help recipients to limit their number of trips outside of the home.

Though we did not find that the Auxilio Emergencial limited trips outside of the home, our finding that receipt or promised receipt of the Auxilio Emergencial in city/state combinations with stringent social distancing policies marginally reduced non-work trips outside the home is promising evidence that, when possible, the poor are responsive to social distancing policies that restrict movement. This further suggests the need to revisit Auxilio Emergencial structure to induce compliance.

Moving forward, policymakers ought to take heed of the findings we present in this paper in an effort to adapt emergency cash transfer programs to be aligned with the types of behavior that promote desirable public health outcomes (Favero and Pedersen, 2020). In doing so, they also ought to pay attention to other downstream effects of enacted social assistance policies, including gender and racial disparities. Absent an inclusive and more coherent approach, the prospects for using emergency aid to reduce the toll of the COVID-19 pandemic on vulnerable populations appears to be limited.

\section{REFERENCES}

Adda, J. (2016). Economic activity and the spread of viral diseases: Evidence from high frequency data. The Quarterly Journal of Economics, 131(2), 891-941. https://doi. org/10.1093/qje/qjw005

Barberia, L., Krieger, J. E., Gutiérrez, M. A., \& Piazza, K. S. (2020). The federal emergency basic income program has positive effects on the income of the most vulnerable population, but fails to reduce mobility. The lack of an integrated strategy undermines the effectiveness of the measures against the pandemic. Rede de Pesquisa Solidária em Políticas Públicas e Sociedade. Note 15. https://redepesquisasolidaria.org/wp-content/uploads/2020/07/boletimpps_15_10julho_ingles.pdf

Barberia, L., Moreira, N., Cantarelli, L. G. R., Claro, M.L., Costa, I. S., de Santana, P., Zamudio, M., Aparecida, D. \& Moraes, T. (2020). COVID-19 Government Response Tracker for the Brazilian Federation (CGRT-BRFED). Repositório de dados do grupo CGRT-BRFED USP https://github.com/cgrtbrfed/covid19brpolicyresponses

Barberia, L. G., Cantarelli, L. G., Oliveira, M. L. C. D. F., Moreira, N. D. P., \& Rosa, I. S. C. (2021). The effect of state-level social distancing policy stringency on mobility in the states of Brazil. Revista de Administração Pública, 55, 27-49.

Bargain, O., \& Aminjonov, U. (2021). Poverty and COVID-19 in Africa and Latin America. World Development, 142, Article 105422. https://doi.org/10.1016/j. worlddev.2021.105422 
LORENA G. BARBERIA AND KELLY SENTERS PIAZZA

THE AUXÍLIO EMERGENCIAL AND STRINGENT SOCIAL DISTANCING POLICIES IN BRAZIL:

THE IMPACT ON MOBILITY AND NON-WORK TRAVEL OUTSIDE THE HOME

Bennett, M. (2021). All things equal? Heterogeneity in policy effectiveness against COVID-19 spread in Chile. World Development, 137, Article 105208. https://doi. org/10.1016/j.worlddev.2020.105208.

Blofield, M., Giambruno, C. \& Filgueira F. (2020). Policy expansion in compressed time. Assessing the speed, breadth and sufficiency of post-COVID-19 social protection measures in 10 Latin American countries. Social Policy, (235), 1-93. https://www.giga-hamburg. de/en/publications/21415466-policy-expansion-compressed-time-assessing-speedbreadth-sufficiency-post-covid-19-social-p/

Brewer, M. \& Tasseva, I. (2020). Did the UK Policy Response to COVID-19 Protect Household Incomes? SSRN. https://ssrn.com/abstract=3628464

Caselli, F. G., Grigoli, F., Sandri, D., \& Spilimbergo, A. (2020). Mobility under the COVID-19 Pandemic: Asymmetric Effects across Gender and Age. (Working Paper 2020/282). International Monetary Fund. https://www.imf.org/en/Publications/WP/ Issues/2020/12/11/Mobility-under-the-COVID-19-Pandemic-Asymmetric-Effectsacross-Gender-and-Age-49918.

Cheng, C., Barceló, J., Hartnett, A. S., Kubinec, R., \& Messerschmidt, L. (2020). COVID-19 Government Response Event Dataset (CoronaNet v.1.0). Nature Human Behavior 4(7), 756-768. https://doi.org/10.1038/s41562-020-0909-7

de Souza, A. A., da Silva, D., de Souza, W. M., Buss, L., Li, S. L., Pereira, R. H. M., Wu, C., Sabino, E. C., \& Faria, N. R. (2021) Dataset on SARS-CoV-2 non-pharmaceutical interventions in Brazilian municipalities. Sci Data 8(73), 1-6. https://doi.org/10.1038/ s41597-021-00859-1

Favero, N., \& Pedersen, M. J. (2020). How to encourage "Togetherness by Keeping Apart" amid COVID-19? The ineffectiveness of prosocial and empathy appeals. Journal of Behavioral Public Administration, 3(2), 1-18. https://doi.org/10.30636/jbpa.32.167

Gentilini, U., Almenfi, M., Orton, I., \& Dale, P. (2020). Social Protection and Jobs Responses to COVID-19: A Real-Time Review of Country Measures. World Bank. https://openknowledge.worldbank.org/handle/10986/33635

Gupta, A., Zhu, H., Doan, M.K., Michuda, A., \& Majumder, B. (2020). Economic Burden of COVID-19 Lockdown on the Poor. SSRN. http://dx.doi.org/10.2139/ssrn.3642987

Gutierrez-Romero, R. (2020). Conflict in Africa during COVID-19: Social Distancing, Food Vulnerability and Welfare Response. (Working Paper). Centre for Globalisation Research. http://dx.doi.org/10.2139/ssrn.3616421

Hale, T., Webster, S., Petherick, A., Phillips, T., \& Kira, B. (2020). Oxford COVID-19 Government Response Tracker. Blavatnik School of Government. https://www.bsg.ox.ac.uk/ research/research-projects/covid-19-government-response-tracker

Hsiang, S., Allen, D., Annan-Phan, S., Bell, K., Bolliger, I., Chong, T., Druckenmiller, H., Huang, L. Y., Hultgren, A., Kraovich, E., Lau, P., Lee, J., Rol, E., Tseng, J., \& Wu, T. (2020) The effect of large-scale anti-contagion policies on the COVID-19 pandemic. Nature 584(7820), 262-267. https://doi.org/10.1038/s41586-020-2404-8

Jay, J., Bor, J., Nsoesie, E. O., Lipson, S. K., Jones, D. K., Galea, S., \& Raifman, J. (2020). Neighbourhood income and physical distancing during the COVID-19 pandemic in the United States. Nature human behaviour, 4(12), 1294-1302. https://doi.org/10.1038/ s41562-020-00998-2 
LORENA G. BARBERIA AND KELLY SENTERS PIAZZA

THE AUXÍLIO EMERGENCIAL AND STRINGENT SOCIAL DISTANCING POLICIES IN BRAZIL: THE IMPACT ON MOBILITY AND NON-WORK TRAVEL OUTSIDE THE HOME

Levy, S., \& Menezes, N. (2021). Evaluating the Impact of the Covid Emergency Aid Transfers on Female Labor Supply in Brazil. Policy Paper (58), 1-26. https://www.insper.edu. br/wp-content/uploads/2021/07/Policy_Paper_58.pdf

Li S.L, Pereira R. H. M., Prete Jr. C. A., et al. Higher risk of death from COVID-19 in low-income and non-White populations of São Paulo, Brazil. BMJ Global Health 2021;6:e004959.

Londoño-Vélez, J., \& Querubin, P. (2020). The Impact of Emergency Cash Assistance in a Pandemic: Experimental Evidence from Colombia. (Working Paper). Innovations for Poverty Action. https://www.poverty-action.org/publication/ impact-emergency-cash-assistance-pandemic-experimental-evidence-colombia

Lustig, N. \& Trasberg, M. (2021) How Brazil and Mexico Diverged on Social Protection in the Pandemic. Current History, 1(120)823, 57-63. https://doi.org/10.1525/ curh.2021.120.823.57

Ma, C., Gu, J., Hou, P., Zhang, L., Bai, Y., Gou, Z., Wu, H., Zhang, B., Li, P. \& Ma, X. (2020). Incidence, clinical characteristics and prognostic factor of patients with COVID-19: a systematic review and meta-analysis. [Prepint Article] MedRxiv. https://doi. org/10.1101/2020.03.17.20037572

Peres, I. T., Bastos, L. S. L., Gelli, J. G. M., Marchesi, J. F., Dantas, L. F, Antunes, B. B. P., Maçaira, P. M.,Baião, F. A., Hamacher, S., \& Bozza, F. A. (2021). Sociodemographic factors associated with COVID-19 in hospital mortality in Brazil. Public Health (192), 1520. https://doi.org/10.1016/j.puhe.2021.01.005

Petherick, A., Kira, B., Goldszmidt, R., \& Barberia, L. (2020). Do Brazil's Covid-19 Government Response Measures Meet the WHO's Criteria for Policy Easing? (Working Paper BSGWP-2020/033). Blavatnik School. https://www.bsg.ox.ac.uk/research/publications/ do-brazils-covid-19-government-response-measures-meet-whos-criteria-policy.

Prates, I., Barbosa, R. J., Requena, C., Lazzari, E., Guicheney, H., Fimiani, H., Leal, J., Flores, P., Simoni, S., Meireles, T., \& Meneces, V. (2020). Dificuldades com aplicativo e não uso da rede de proteção atual limitam acesso ao auxílio de emergência. Rede de Pesquisa Solidária em Políticas Públicas e Sociedade. Note 5. https://redepesquisasolidaria.org/ wp-content/uploads/2020/05/boletim5.pdf

Ribeiro, K. B., Ribeiro, A. F., de Sousa, M. A., \& Castro, M. C. (2021). Social inequalities and COVID-19 mortality in the city of São Paulo, Brazil. International Journal of Epidemiology, 50(3), 732-742. https://doi.org/10.1093/ije/dyab022

Ritchie, H., Mathieu, E., Rodés-Guirao, L., Appel, C., Giattino, C., Ortiz-Ospina, E., Hasell, J., Macdonald, B., Beltekian, D., \& Roser, M. (2020) "Coronavirus Pandemic (COVID-19)". Published online at OurWorldInData.org. Retrieved from: 'https://ourworldindata.org/ coronavirus' [Online Resource]

Weill, J. A., Stigler, M., Deschenes, O., \& Springborn, M. R. (2020). Social distancing responses to COVID-19 emergency declarations strongly differentiated by income. Proceedings of the National Academy of Sciences, 117(33), 19658-19660. https://doi. org/10.1073/pnas.2009412117

Woskie, L., \& Wenham, C. (2021). Do Men and Women "Lockdown" Differently? Examining Panama's Covid-19 Sex-Segregated Social Distancing Policy. Feminist Economics, 27(1), 327-344. https://doi.org/10.1080/13545701.2020.1867761 


\section{APPENDIX}

Table A1. The Effect of Emergency Cash Transfers and Social Distancing Policies on Number of Trips Outside the Home (Auxilio=Auxilio Recipients + Promised Recipients)

\begin{tabular}{lllll}
\hline \multicolumn{4}{c}{ Dependent variable: } \\
\cline { 2 - 4 } & \multicolumn{4}{c}{ Number of Days Outside the Home } \\
\hline
\end{tabular}

Auxílio Emergencial (vs. Not Eligible) $1.386^{* * *}$

$(0.515)$

Auxílio Emergencial (vs. Not Eligible, Applied)

(0.718)

Auxílio Emergencial (vs. Eligible,

Didn't Apply)

(1.063)

Auxílio Emergencial (vs. Eligible,

Applied, Didn't Receive)

0.983

(0.738)

Rio de Janeiro, RJ

$\begin{array}{llll}-0.010 & -0.253 & -2.334^{*} & -0.137 \\ (0.394) & (0.941) & (1.314) & (0.931)\end{array}$

Porto Alegre, RS $0.527 \quad-0.224 \quad-0.050$ 1.218 (0.391)

(1.173)

(1.271) (1.096)

Goioania, GO

$$
0.968^{* *}
$$

0.219

$-0.181$

$-0.099$

(0.418) (0.855)

(1.257)

(0.861)

Fortaleza, CE

$0.451 \quad 0.570$

$-0.447$

$-0.815$

(0.420) (0.903)

(1.302)

(0.915)

Salvador, BA
0.430

0.494 


\begin{tabular}{|c|c|c|c|c|}
\hline & \multicolumn{4}{|c|}{ Dependent variable: } \\
\hline & \multicolumn{4}{|c|}{ Number of Days Outside the Home } \\
\hline & (1) & (2) & (3) & (4) \\
\hline & (0.439) & $(0.920)$ & $(1.314)$ & $(0.890)$ \\
\hline \multirow[t]{2}{*}{ Manaus, AM } & -0.029 & 0.563 & $-2.834^{* *}$ & -0.090 \\
\hline & $(0.470)$ & $(0.992)$ & $(1.216)$ & $(0.912)$ \\
\hline \multirow[t]{2}{*}{ Recife, PE } & -0.161 & 0.119 & 0.206 & -0.742 \\
\hline & $(0.436)$ & $(0.975)$ & $(1.339)$ & $(0.876)$ \\
\hline \multirow[t]{2}{*}{ Female } & $-1.534^{* * *}$ & $-1.649^{* * *}$ & $-1.586^{* * *}$ & $-1.259^{* * *}$ \\
\hline & $(0.188)$ & $(0.286)$ & (0.289) & $(0.282)$ \\
\hline \multirow[t]{2}{*}{ Education } & -0.047 & -0.047 & -0.014 & 0.048 \\
\hline & $(0.072)$ & $(0.127)$ & $(0.126)$ & $(0.122)$ \\
\hline \multirow[t]{2}{*}{ White } & -0.076 & -0.262 & $-0.588^{* *}$ & -0.233 \\
\hline & (0.199) & $(0.296)$ & (0.297) & $(0.295)$ \\
\hline \multirow[t]{2}{*}{ Number of Neighbors } & 0.022 & -0.005 & -0.009 & -0.006 \\
\hline & $(0.020)$ & $(0.024)$ & $(0.016)$ & $(0.025)$ \\
\hline \multirow[t]{2}{*}{ Household Income Movement } & -0.078 & 0.055 & 0.162 & 0.159 \\
\hline & $(0.160)$ & $(0.223)$ & $(0.222)$ & $(0.226)$ \\
\hline \multirow[t]{2}{*}{ COVID Risk } & -0.051 & -0.096 & -0.148 & -0.146 \\
\hline & $(0.112)$ & (0.149) & (0.159) & $(0.146)$ \\
\hline
\end{tabular}

Auxílio Emergencial (vs. Not

Eligible)*Rio de Janeiro, RJ

$-1.979^{* *}$

(0.769)

Auxílio Emergencial (vs. Not Eligible)*Porto Alegre, RS
$-1.968^{* *}$

(0.817) 


\section{Dependent variable:}

Number of Days Outside the Home

(1)

(2)

(3)

(4)
Auxílio Emergencial (vs. Not Eligible)*Goiania, GO

$-1.869^{* *}$

(0.781)

Auxílio Emergencial (vs. Not Eligible)*Fortaleza, CE

(0.749)

Auxílio Emergencial (vs. Not Eligible)*Salvador, BA

(0.739)

Auxílio Emergencial (vs. Not Eligible)* Manaus, AM

$-1.775^{*}$

(0.795)

Auxílio Emergencial (vs. Not

Eligible) ${ }^{*}$ Recife, PE

$-1.265^{*}$

(0.755)

Auxílio Emergencial (vs. Not Eligible, Applied) )*Rio de Janeiro, RJ

Auxílio Emergencial (vs. Not Eligible, Applied)*Porto Alegre, RS

Auxílio Emergencial (vs. Not Eligible, Applied)*Goiania, GO

Auxílio Emergencial (vs. Not Eligible, Applied)*Fortaleza, CE 


\begin{tabular}{c} 
Dependent variable: \\
\cline { 2 - 4 } \\
\cline { 2 - 4 } Number of Days Outside the Home \\
\hline
\end{tabular}

Auxílio Emergencial (vs. Not Eligible, Applied)*Salvador, BA

Auxílio Emergencial (vs. Not Eligible, Applied)*Manaus, AM

Auxílio Emergencial (vs. Not Eligible, Applied)*Recife, PE

Auxílio (vs. Eligible, Didn't Apply)*Rio de Janeiro, RJ

Auxílio Emergencial (vs. Eligible, Didn't Apply)*Porto Alegre, RS

Auxílio Emergencial (vs. Eligible, Didn't Apply)*Goiania, GO

Auxílio Emergencial (vs. Eligible, Didn't Apply)*Fortaleza, CE

Auxílio Emergencial (vs. Eligible, Didn't Apply)*Salvador, BA

Auxílio Emergencial (vs. Eligible, Didn't Apply)*Manaus, AM 


\section{\begin{tabular}{c} 
Dependent variable: \\
\hline Number of Days Outside the Home
\end{tabular}}

(1)

(2)

(3)

(4)

Auxílio Emergencial (vs. Eligible,

Didn't Apply)*Recife, RE

Auxílio Emergencial (vs. Eligible, Applied, Didn't Receive)*Rio de Janeiro, RJ

Auxílio Emergencial (vs. Eligible, Applied, Didn't Receive)*Porto Alegre, RS

Auxílio Emergencial (vs. Eligible, Applied, Didn't Receive)*Goiania, GO

$-0.751$

Auxílio Emergencial (vs. Eligible, Applied, Didn't Receive)*Fortaleza, CE

Auxílio Emergencial (vs. Eligible, Applied, Didn't Receive)*Salvador, BA

Auxílio Emergencial (vs. Eligible,

Applied, Didn't Receive)*Manaus, AM

Auxílio Emergencial (vs. Eligible, Applied, Didn't Receive)*Recife, PE

Constant $4.540^{* * *}$ $4.687^{* *+}$ $5.576^{* * *}$ $4.311^{* * *}$ 


\begin{tabular}{|c|c|c|c|c|}
\hline & \multicolumn{4}{|c|}{ Dependent variable: } \\
\hline & \multicolumn{4}{|c|}{ Number of Days Outside the Home } \\
\hline & (1) & (2) & (3) & (4) \\
\hline & $(0.475)$ & (0.793) & $(1.155)$ & $(0.812)$ \\
\hline Observations & 974 & 419 & 379 & 437 \\
\hline $\mathrm{R}^{2}$ & 0.091 & 0.117 & 0.153 & 0.085 \\
\hline Adjusted $\mathrm{R}^{2}$ & 0.071 & 0.070 & 0.103 & 0.039 \\
\hline Residual Std. Error & $\begin{array}{c}2.845 \\
(\mathrm{df}=952)\end{array}$ & $\begin{array}{c}2.677 \\
(\mathrm{df}=397)\end{array}$ & $\begin{array}{c}2.574 \\
(\mathrm{df}=357)\end{array}$ & $\begin{array}{c}2.713 \\
(\mathrm{df}=415)\end{array}$ \\
\hline F Statistic & $\begin{array}{c}4.543^{* * *}(\mathrm{df}= \\
21 ; 952)\end{array}$ & $\begin{array}{c}=2.508^{* * *}(\mathrm{df}= \\
21 ; 397)\end{array}$ & $\begin{array}{r}=3.066^{* * *}(\mathrm{df}= \\
21 ; 357)\end{array}$ & $\begin{array}{c}1.835^{* *}(\mathrm{df}= \\
21 ; 415)\end{array}$ \\
\hline
\end{tabular}

Note: ${ }^{*} \mathrm{p}^{* *} \mathrm{p}^{* * *} \mathrm{p}<0.01$

Source: Petherick et al. (2020); Barberia et al. (2020).

Table 2. The Effect of Emergency Cash Transfers and Social Distancing Policies on Number of Trips Outside the Home (Auxílio=Auxílio Recipients Only)

\begin{tabular}{c} 
Dependent variable \\
\cline { 2 - 3 } \\
\cline { 2 - 3 }
\end{tabular}

Auxílio Emergencial (vs. Not Eligible)

$1.089^{* *}$

(0.453)

Auxílio Emergencial (vs. Not Eligible,

Applied)

0.984

(0.695)

Auxílio Emergencial (vs. Eligible,

Didn't Apply)

Rio de Janeiro, RJ

$\begin{array}{ll}-0.013 & -0.231 \\ (0.395) & (0.961)\end{array}$

(0.395) (0.961) 


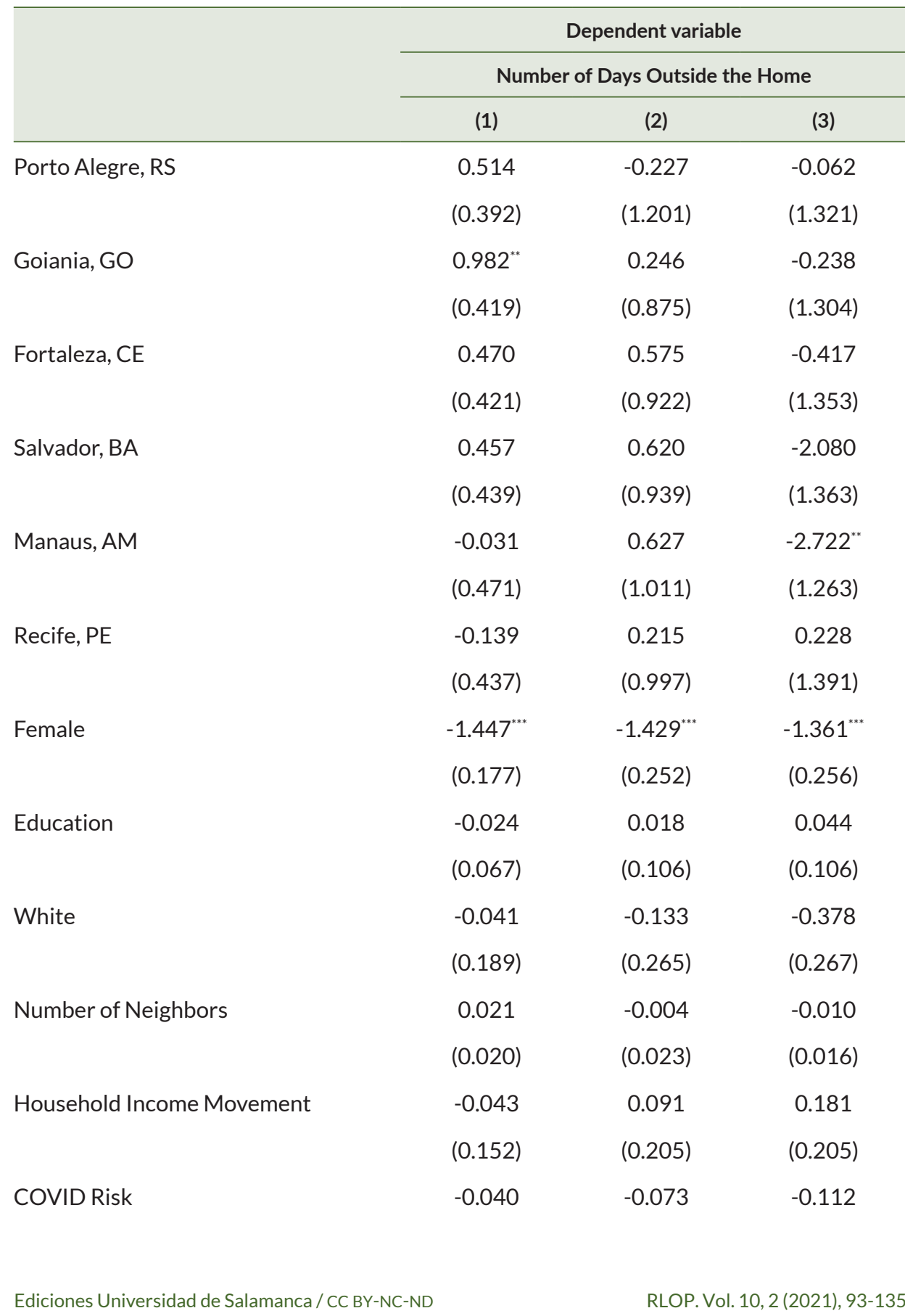




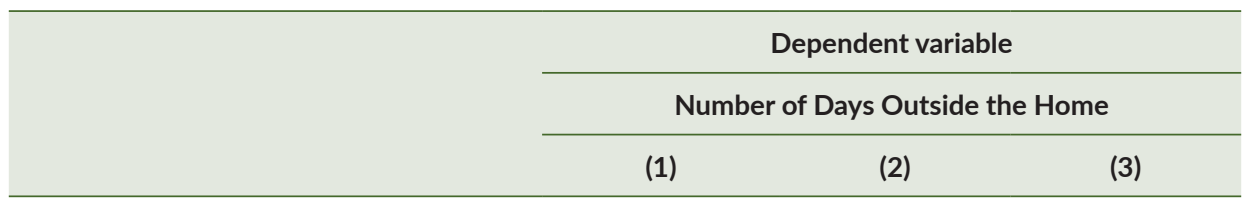

(0.103) (0.132) (0.139)

Auxílio Emergencial (vs. Not Eligible)*Rio de Janeiro, RJ

Auxílio Emergencial (vs. Not Eligible)*Porto Alegre, RS

Auxílio Emergencial (vs. Not Eligible)*Goiania, GO

Auxílio Emergencial (vs. Not Eligible)*Fortaleza, CE

Auxílio Emergencial (vs. Not Eligible)*Salvador, BA

Auxílio Emergencial (vs. Not Eligible)*Manaus, AM

Auxílio Emergencial (vs. Not Eligible) ${ }^{*}$ Recife, $\mathrm{PE}$

Auxílio Emergencial (vs. Not Eligible, Applied)*Rio de Janeiro, RJ

Auxílio Emergencial (vs. Not Eligible, Applied)*Porto Alegre, RS 


\begin{tabular}{clc}
\hline & \multicolumn{2}{c}{ Dependent variable } \\
\cline { 2 - 3 } & \multicolumn{2}{c}{ Number of Days Outside the Home } \\
\cline { 2 - 4 } & $(1)$ & $(2)$ \\
\hline
\end{tabular}

Auxílio Emergencial (vs. Not Eligible, Applied)*Goiania, GO

Auxílio Emergencial (vs. Not Eligible, Applied)*Fortaleza, CE

Auxílio Emergencial (vs. Not Eligible, Applied)*Salvador, BA

Auxílio Emergencial (vs. Not Eligible, Applied)*Manaus, AM

Auxílio Emergencial (vs. Not Eligible, Applied)*Recife, PE

Auxílio Emergencial (vs. Eligible,

Didn't Apply)*Rio de Janeiro, RJ

Auxílio Emergencial (vs. Eligible,

Didn't Apply)*Porto Alegre, RS

Auxílio Emergencial (vs. Eligible,

Didn't Apply)*Goiania, GO

Auxílio Emergencial (vs. Eligible,

Didn't Apply)*Fortaleza, CE 


\begin{tabular}{c} 
Dependent variable \\
\cline { 2 - 3 } \\
\cline { 2 - 3 }
\end{tabular}

Auxílio Emergencial (vs. Eligible,

Didn't Apply)*Salvador, BA

Auxílio Emergencial (vs. Eligible,

Didn't Apply)*Manaus, AM

Auxílio Emergencial (vs. Eligible,

Didn't Apply)*Recife, PE

\begin{tabular}{lccc} 
Constant & $4.336^{* * *}$ & $4.226^{* * *}$ & $5.095^{* * *}$ \\
\hline Observations & $(0.459)$ & $(0.759)$ & $(1.154)$ \\
$\mathrm{R}^{2}$ & 1,108 & 553 & 513 \\
Adjusted R & 0.079 & 0.082 & 0.102 \\
Residual Std. Error & 0.061 & 0.045 & 0.064 \\
F Statistic & $2.855(\mathrm{df}=1086)$ & $2.743(\mathrm{df}=531)$ & $2.677(\mathrm{df}=491)$ \\
& $4.407^{* * *}$ & $2.252^{* * *}$ & $2.663^{* * *}$ \\
\hline
\end{tabular}

Note: ${ }^{*} \mathrm{p}^{* *} \mathrm{p}^{* * *} \mathrm{p}<0.01$

Source: Petherick et al. (2020); Barberia et al. (2020). 
LORENA G. BARBERIA AND KELLY SENTERS PIAZZA

THE AUXÍLIO EMERGENCIAL AND STRINGENT SOCIAL DISTANCING POLICIES IN BRAZIL:

THE IMPACT ON MOBILITY AND NON-WORK TRAVEL OUTSIDE THE HOME

Table 3. The Effect of Emergency Cash Transfers and Social Distancing Policies on Number of Reasons for Non-Work Trips (Auxílio=Auxílio Recipients + Promised Recipients)

\begin{tabular}{lllll}
\hline & \multicolumn{3}{c}{ Dependent variable } \\
\cline { 2 - 3 } & \multicolumn{3}{c}{ Leaving Home For Non-Work Reasons } \\
\cline { 2 - 4 } & (1) & (2) & (3)
\end{tabular}

Auxílio Emergencial (vs. Not Eligible) 0.313

(0.304)

Auxílio Emergencial (vs. Not Eligible, Applied) 0.692 (0.492)

Auxílio Emergencial (vs. Eligible, Didn't Apply) $-0.410$ (0.532)

Auxílio (vs. Eligible, Applied, Didn't Receive) 0.143 (0.468)

Rio de Janeiro, RJ

$\begin{array}{llll}0.431^{*} & 0.747 & -0.357 & -0.017\end{array}$

Porto Alegre, RS

$\begin{array}{llll}(0.229) & (0.651) & (0.720) & (0.601)\end{array}$

Porto Alegre, RS

$\begin{array}{llll}0.681^{\cdots *} & -0.076 & -0.344 & 0.612\end{array}$

Goiania, GO

$\begin{array}{llll}(0.219) & (0.711) & (0.704) & (0.622)\end{array}$

Goiania, GO

$\begin{array}{llll}0.516^{\prime \prime} & 1.016^{\circ} & -0.358 & -0.127\end{array}$

Fortaleza, CE

$\begin{array}{llll}(0.232) & (0.557) & (0.644) & (0.536)\end{array}$

Fortaleza, CE

$-0.418^{*}-0.199-1.569^{* *} \quad 0.083$

Salvador, BA

$\begin{array}{llll}(0.247) & (0.615) & (0.774) & (0.556)\end{array}$

Manaus, AM

$0.148 \quad 0.598-1.237^{*}-0.164$

$\begin{array}{llll}(0.244) & (0.579) & (0.669) & (0.559)\end{array}$

$0.2241 .074^{*}-2.043^{* * *} 0.226$

Recife, PE

$\begin{array}{llll}(0.249) & (0.639) & (0.751) & (0.563)\end{array}$

$\begin{array}{llll}0.428^{*} & 0.915 & -1.139^{*} & -0.059\end{array}$ 


\begin{tabular}{lccccc}
\hline & \multicolumn{4}{c}{ Dependent variable } \\
\cline { 2 - 5 } & \multicolumn{3}{c}{ Leaving Home For Non-Work Reasons } \\
\cline { 2 - 5 } Female & $(1)$ & $(2)$ & $(3)$ & $(4)$ \\
\hline Education & $(0.238)$ & $(0.587)$ & $(0.665)$ & $(0.534)$ \\
& $-0.820^{* * *}$ & $-0.856^{* * *}$ & $-0.777^{* * *}$ & $-0.788^{* * *}$ \\
White & $(0.105)$ & $(0.173)$ & $(0.180)$ & $(0.168)$ \\
& 0.009 & 0.015 & -0.055 & 0.026 \\
Number of Neighbors & $(0.039)$ & $(0.078)$ & $(0.080)$ & $(0.072)$ \\
& $-0.452^{* * *}$ & -0.250 & $-0.348^{*}$ & -0.264 \\
Household Income Movement & $(0.113)$ & $(0.188)$ & $(0.192)$ & $(0.180)$ \\
COVID Risk & 0.003 & -0.014 & -0.013 & -0.018 \\
& $(0.008)$ & $(0.016)$ & $(0.014)$ & $(0.017)$ \\
& 0.105 & $0.235^{*}$ & 0.169 & $0.283^{* *}$ \\
& $(0.088)$ & $(0.134)$ & $(0.141)$ & $(0.136)$ \\
& 0.092 & $0.197^{* *}$ & $0.226^{* *}$ & 0.141 \\
& $(0.063)$ & $(0.093)$ & $(0.100)$ & $(0.087)$
\end{tabular}

Auxílio Emergencial (vs. Not Eligible)*Rio de Janeiro, RJ

$-0.690$

(0.469)

Auxílio Emergencial (vs. Not Eligible)*Porto Alegre, RS

(0.462)

Auxílio Emergencial (vs. Not Eligible)*Goiania, GO

$-0.556$

(0.451)

Auxílio Emergencial (vs. Not Eligible)*Fortaleza, CE

$-0.419$

(0.443)

Auxílio Emergencial (vs. Not Eligible)*Salvador, BA

$-0.336$ 


\section{Dependent variable}

Leaving Home For Non-Work Reasons

(1)

(2)

(3)

(4)

(0.428)

Auxílio Emergencial (vs. Not Eligible)*Manaus, AM $-0.683$

(0.435)

Auxílio Emergencial (vs. Not Eligible)*Recife, PE $-0.973^{* *}$

(0.440)

Auxílio Emergencial (vs. Not Eligible, Applied)*Rio de Janeiro, RJ

(0.772)

Auxílio Emergencial (vs. Not Eligible, Applied)*Porto Alegre, RS

Auxílio Emergencial (vs. Not Eligible, Applied)*Goiania, GO

Auxílio Emergencial (vs. Not Eligible, Applied)*Fortaleza, CE

Auxílio Emergencial (vs. Not Eligible, Applied)*Salvador, BA

Auxílio Emergencial (vs. Not Eligible, Applied)*Manaus, AM

Auxílio Emergencial (vs. Not Eligible, Applied)*Recife, PE 
Dependent variable

Leaving Home For Non-Work Reasons

(1)

Auxílio Emergencial (vs. Eligible, Didn't Apply)*Rio de Janeiro, RJ
(3)

(4)

Auxílio Emergencial (vs. Eligible, Didn't Apply)*Porto Alegre, RS

Auxílio Emergencial (vs. Eligible, Didn't Apply)*Goiania, GO

Auxílio Emergencial (vs. Eligible, Didn't Apply)*Fortaleza, CE

Auxílio Emergencial (vs. Eligible, Didn't Apply)*Salvador, BA

Auxílio Emergencial (vs. Eligible, Didn't Apply)*Manaus, AM

Auxílio Emergencial (vs. Eligible, Didn't Apply)*Recife, PE

Auxílio (vs. Eligible, Applied, Didn't Receive)*Rio de Janeiro, RJ

Auxílio (vs. Eligible, Applied, Didn't Receive)*Porto Alegre, RS 


\section{Dependent variable}

Leaving Home For Non-Work Reasons
(2)

(3)

Auxílio (vs. Eligible, Applied, Didn't Receive)*Goiania, GO

Auxílio (vs. Eligible, Applied, Didn't Receive)*Fortaleza, CE

Auxílio (vs. Eligible, Applied, Didn't Receive)*Salvador, BA

Auxílio (vs. Eligible, Applied, Didn't Receive)*Manaus, AM

Auxílio (vs. Eligible, Applied, Didn't Receive)*Recife, PE

(0.649)

\begin{tabular}{lrrrr}
\hline Observations & 1,336 & 537 & 501 & 564 \\
\hline
\end{tabular}

Note: ${ }^{*} \mathrm{p}^{* *} \mathrm{p}^{* * *} \mathrm{p}<0.01$

Source: Petherick et al. (2020); Barberia et al. (2020).

Table 4. The Effect of Emergency Cash Transfers and Social Distancing Policies on Number of Reasons for Non-Work Trips (Auxílio=Auxílio Recipients Only)

\begin{tabular}{lll}
\hline & \multicolumn{2}{c}{ Dependent variable } \\
\cline { 2 - 3 } Leaving Home For Non-Work Reasons \\
\hline (1)
\end{tabular}

Auxílio Emergencial (vs. Not Eligible)

0.275

(0.267)

Auxílio Emergencial (vs. Not Eligible, Applied) 


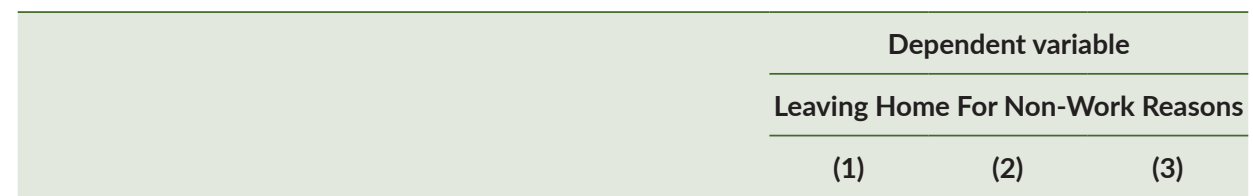

(0.468)

Auxílio Emergencial (vs. Eligible, Didn’t Apply) $-0.373$

(0.505)

Rio de Janeiro, RJ

$\begin{array}{ccc}0.434^{*} & 0.757 & -0.253 \\ (0.228) & (0.643) & (0.715)\end{array}$

Porto Alegre, RS

$0.671^{* * *}-0.069-0.326$

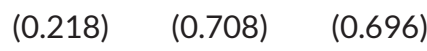

Goiania, GO

$\begin{array}{lll}0.520^{* *} & 0.983^{*} & -0.307\end{array}$

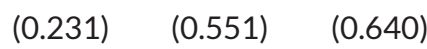

Fortaleza, CE

$\begin{array}{lll}-0.402 & -0.203 & -1.470 *\end{array}$

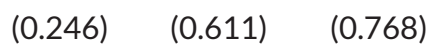

Salvador, BA

$0.1620 .576-1.166^{*}$

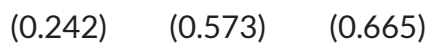

Manaus, AM

$0.2401 .060^{*}-1.962^{* * *}$

$\begin{array}{lll}\text { (0.247) (0.628) (0.746) } & \text { (0.6) }\end{array}$

Recife, PE

$\begin{array}{lll}0.438^{*} & 0.912 & -1.035\end{array}$

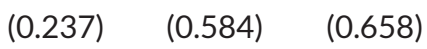

Female $-0.824^{* * *} \quad-0.863^{* * *} \quad-0.805^{* * *}$

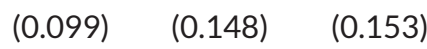

Education $\begin{array}{lll}0.018 & 0.038 & -0.007\end{array}$

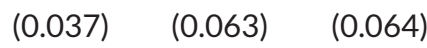

White $-0.415^{* * *}-0.217-0.285^{*}$

(0.106) (0.161) (0.163) 


\begin{tabular}{lcccc}
\hline & \multicolumn{3}{c}{ Dependent variable } \\
\cline { 2 - 4 } & \multicolumn{1}{c}{ Leaving Home For Non-Work Reasons } \\
\cline { 2 - 4 } & $(1)$ & $(2)$ & $(3)$ \\
\hline Number of Neighbors & 0.003 & -0.014 & -0.013 \\
Household Income Movement & $(0.008)$ & $(0.015)$ & $(0.013)$ \\
& 0.120 & $0.241^{* *}$ & 0.184 \\
COVID Risk & $(0.084)$ & $(0.120)$ & $(0.125)$ \\
& 0.080 & $0.144^{*}$ & $0.160^{*}$ \\
& $(0.058)$ & $(0.079)$ & $(0.084)$
\end{tabular}

Auxílio Emergencial (vs. Not Eligible)*Rio de Janeiro, RJ

(0.408)

Auxílio Emergencial (vs. Not Eligible)*Porto Alegre, RS $\quad-0.511$

(0.404)

Auxílio Emergencial (vs. Not Eligible)* Goiania, GO $-0.614$

(0.388)

Auxílio Emergencial (vs. Not Eligible)*Fortaleza, CE $-0.143$

(0.392)

Auxílio Emergencial (vs. Not Eligible)*Salvador, BA $-0.342$

(0.382)

Auxílio Emergencial (vs. Not Eligible)*Manaus, AM $-0.488$

Auxílio Emergencial (vs. Not Eligible)*Recife, PE $-0.814^{* *}$

(0.384)

Auxílio Emergencial (vs. Not Eligible, Applied)*Rio de Janeiro, RJ 


\section{Dependent variable}

Leaving Home For Non-Work Reasons

(1)

(2)

(3)

Auxílio Emergencial (vs. Not Eligible, Applied)*Porto Alegre, RS

Auxílio Emergencial (vs. Not Eligible, Applied) ${ }^{*}$ Goiania, GO

Auxílio Emergencial (vs. Not Eligible, Applied)*Fortaleza, CE

Auxílio Emergencial (vs. Not Eligible, Applied)*Salvador, BA

Auxílio Emergencial (vs. Not Eligible, Applied)*Manaus, AM

Auxílio Emergencial (vs. Not Eligible, Applied)*Recife, PE

Auxílio Emergencial (vs. Eligible, Didn't Apply)*Rio de Janeiro, RJ

Auxílio Emergencial (vs. Eligible, Didn't Apply)*Porto Alegre, RS

Auxílio Emergencial (vs. Eligible, Didn't Apply)*Goiania, GO 


\section{Dependent variable}

Leaving Home For Non-Work Reasons

(1)

(2)

(3)

Auxílio Emergencial (vs. Eligible, Didn't Apply)*Fortaleza, CE

Auxílio Emergencial (vs. Eligible, Didn't Apply)*Salvador, BA

Auxílio Emergencial (vs. Eligible, Didn't Apply)*Manaus, AM

Auxílio Emergencial (vs. Eligible, Didn't Apply)*Recife, PE

(0.722)

\begin{tabular}{llll}
\hline Observations & 1,515 & 716 & 680 \\
\hline
\end{tabular}

Note: ${ }^{*} \mathrm{p}^{* *} \mathrm{p}^{* * *} \mathrm{p}<0.01$

Source: Petherick, et al. (2020); Barberia et al. (2020). 
